\title{
The link between Hawaiian mantle plume composition, magmatic flux, and deep mantle geodynamics
}

Lauren Harrison* and Dominique Weis, Pacific Centre for Isotopic and Geochemical

Research, Department of Earth, Ocean, and Atmospheric Sciences, University of British

Columbia, 2020-2207 Main Mall, Vancouver, Vancouver, B.C., V6T 1Z4, Canada,

1harriso@eoas.ubc.ca

Michael O. Garcia, Department of Geology and Geophysics, University of Hawai‘i, Mānoa, Honolulu, HI, 96822 USA

Keywords: Oceanic island basalts, $\mathrm{Pb}$ isotopes, Hawaii, Mantle dynamics, LLSVP, Northwest Hawaiian Ridge; Mantle plume

\begin{abstract}
Oceanic island basalts sample mantle reservoirs that are isotopically and compositionally heterogeneous. The Hawaiian-Emperor chain represents $~ 85 \mathrm{Myr}$ of volcanism supplied by a deep mantle plume. Two geographically and geochemically delineated trends, Kea and Loa, are well documented within the Hawaiian Islands. Enriched Loa compositions originate from subduction recycled or primordial material stored in deep mantle reservoirs such as the large low shear velocity province (LLSVP) below Hawai'i. Loa compositions have not been observed along the Emperor Seamounts ( $>50 \mathrm{Ma})$, whereas lavas on the Hawaiian Islands $(<6.5 \mathrm{Ma})$ sample both Kea and Loa sources. Lead isotopes in shield lavas along the Northwest Hawaiian Ridge (NWHR) spanning 42 Myr between the bend in the chain and the Hawaiian Islands record the geochemical evolution of the Hawaiian mantle plume over a time period when many geophysical parameters (volcanic propagation rate, magmatic flux, mantle potential temperature) increased significantly. Along the NWHR, the Loa geochemical component appears ephemerally, which we link to the sampling of different lower mantle compositional domains by the Hawaiian mantle
\end{abstract}


25 plume. The plume initially sampled only the deep Pacific mantle (Kea component) from outside

26 the LLSVP during the formation of the Emperor Seamounts. Southward migration and anchoring

27 of the plume on the LLSVP led to entrainment of increasing amounts of LLSVP material (Loa

28 component) along the NWHR as documented by an increase in ${ }^{208} \mathrm{~Pb}^{*} /{ }^{206} \mathrm{~Pb} *$ with decreasing

29 age. The correlation between ${ }^{208} \mathrm{~Pb} * 206 \mathrm{~Pb}^{*}$ and magmatic flux suggests source composition

30 affects the magmatic flux, and explains why the Hawaiian mantle plume has dramatically

31 strengthened through time.

\section{Introduction}

Long-lived intraplate oceanic islands and chains such as Iceland, Kerguelen, and Hawai'i

34 are typically explained as the products of mantle plumes (Morgan, 1972; Boschi et al., 2007).

35 Hawai' $i$ is one of the most studied examples of such volcanism because it has a well-documented age progression along the chain (O’Connor et al., 2013; Garcia et al., 2015), is far from continent and mid-ocean ridge sources of contamination, has a deep mantle source (French and Romanowicz, 2015), and, on the main islands, exhibits two geographical trends, Kea and Loa, with distinct geochemical signatures (Abouchami et al., 2005; Tanaka et al., 2008; Weis et al., 2011). Hawai' $i$, the archetypal mantle plume, is anomalous in many of its dynamic and geochemical features. For example, intraplate lavas worldwide are dominantly alkalic in composition, reflecting lower degrees of partial melting, in comparison to Hawai' $i$ where $~ 98 \%$ of eruptive products are of tholeiitic composition (Garcia et al., 2015). In addition, mantle plumes

44 typically exhibit higher magmatic production at their initial arrival at the base of the lithosphere 45 that dramatically diminishes with time, i.e. from melting the plume head to the plume tail (White, 1993; Jellinek and Manga, 2004; Kumagai et al., 2008). The volume flux of Hawaiian eruptive

47 products, conversely, has increased $\sim 650 \%$ along the NWHR and an additional $\sim 375 \%$ during the 
formation of the Hawaiian Islands to an all-time high at the current locus of volcanism centered

49 on Kilauea and Lō'ihi volcanoes (Wessel, 2016). At the same time, mantle potential temperature

50 has increased (Tree, 2016), along with the volcano propagation rate (i.e. the frequency that a new

51 volcano is created as the Pacific Plate moves over the Hawaiian mantle plume; O'Connor et al.,

52 2013). Thus, on the basis of most major physical parameters, the Hawaiian mantle plume has

53 strengthened, an unexplained observation that is a very unusual feature among mantle plumes

54 worldwide (Tree, 2016). No modern geochemical study has addressed this issue or determined the

55 isotopic variation along the NWHR, to evaluate whether source changes have played a role.

56 The source of the Loa component in Hawaiian lavas is more enriched (higher Th/U,

$57{ }^{208} \mathrm{~Pb}^{*} /{ }^{206} \mathrm{~Pb}^{*}$, and $\mathrm{Sr}$ isotopic ratios; lower $\mathrm{Nd}$ and $\mathrm{Hf}$ isotopic ratios) than that of the Kea

58 component. This signature is predominately explained by the presence of subduction recycled

59 material (Weis et al., 2011) or primordial material in the deep source (Li et al., 2015). Lead

60 isotopes provide the most robust tool for delineating the Loa and Kea components in Hawaiian

61 basalts: at a given ${ }^{206} \mathrm{~Pb} /{ }^{204} \mathrm{~Pb}$, Loa-trend volcanoes will have a higher ${ }^{208} \mathrm{~Pb} /{ }^{204} \mathrm{~Pb}$ than Kea trend

62 volcanoes (Abouchami et al., 2005; Weis et al., 2011). Emperor Seamount lavas (85-51 Ma) are

63 Kea-like in geochemical affinity, whereas both Kea and Loa compositions are present in lavas

64 from the Hawaiian Islands, and furthermore are clearly distributed along two geographical trends

65 of volcanoes (Fig. 1; Keller et al., 2000; Regelous et al., 2003; Abouchami et al., 2005; Tanaka et

66 al., 2008; Weis et al., 2011). On the basis of the only three Pb isotope analyses previously

67 available for the NWHR, Loa geochemical compositions have been observed at only one

68 seamount, Daikakuji, near the bend in the Hawaiian-Emperor chain (Regelous et al., 2003). It was

69 unknown whether this is an isolated case or represents the first arrival of the Loa geochemical

70 component (Garcia et al., 2015). Furthermore, because the Loa composition typically is 
71 associated with a more fusible source component, its presence may be linked to the dramatic

72 increase in volcano volume (lowest at Daikakuji with $30 \mathrm{~km}^{3}$ to highest at Gardner with $540 \mathrm{~km}^{3}$;

73 Bargar and Jackson, 1974), magmatic flux $\left(0.4 \mathrm{~m}^{3} / \mathrm{s}\right.$ at Daikakuji to a maximum of $4 \mathrm{~m}^{3} / \mathrm{s}$ at

74 Gardner; Wessel, 2016), and volcanic propagation rate (Detroit to Midway $57 \pm 2 \mathrm{~km} / \mathrm{Myr}$, from

75 which increases to 80-100 km/Myr afterwards; O'Connor et al., 2013) observed along the 2800

76 km long ridge (Pertermann and Hirschmann, 2003; Garcia et al., 2015).

77 Lead isotopic compositions were measured on 22 shield-stage samples from 13 NWHR

78 volcanoes spanning from $\sim 47 \mathrm{Ma}$ at the bend to $\sim 7 \mathrm{Ma}$ at Nīhoa (Fig. 1; Dalrymple et al., 1974;

79 O’Connor et al., 2013). There were no Pb isotopic measurements for NWHR volcanoes younger

80 than Daikakuji Seamount; this study fills this critical 40 million year gap. The Pb isotopic

81 evolution of the entire Hawaiian-Emperor Seamount chain was examined to identify when the

82 enriched Loa component appears and to assess its involvement in magmatic flux variations.

83 Finally, we discuss the implications of these results for the Hawaiian deep mantle source and the

84 potential contribution of material from the Pacific LLSVP to account for flux variations.

85 2. Geological setting and sampling

86 Fifty-one volcanoes erupted over $\sim 42$ million years between the bend in the Hawaiian-

87 Emperor chain and the Hawaiian Islands constitute the Northwest Hawaiian Ridge (NWHR;

88 Garcia et al., 2015). We focus on shield stage tholeiitic lavas because they are most likely to

89 record the plume source composition variation (i.e. Loa and Kea geochemical variation), whereas

90 the later post-shield and rejuvenated Hawaiian lavas present a uniform depleted isotopic

91 composition regardless of the geochemical affinity of shield stage lavas at the same volcano (Frey

92 et al., 2005; Hanano et al., 2010). Study of the Hawaiian Islands show that single islands are

93 composed of several volcanic centers which may erupt different geochemical signatures from as 
94 close as $~ 50$ km apart (e.g. Mauna Loa and Mauna Kea on Hawai'i; Abouchami et al., 2005). One

95 to four samples from selected volcanoes were available for this large-scale study, which

96 consequently provides average isotopic trends along a previously unstudied section of the

97 Hawaiian-Emperor chain.

Sampling of the NWHR is currently highly restricted by the Papahānaumokuākea Marine

99 National Monument, a recently expanded $\sim 1,508,870 \mathrm{~km}^{2}$ U.S. Marine Conservation Area and

100 UNESCO World Heritage Site that stretches from Middle Bank to Hancock Seamount ( $80 \%$ of

101 the NWHR). Because of this access impediment, samples in this study originate from pre-2006

102 dredge or island sampling expeditions stored at the University of Hawai' $i$ and Scripps Institution

103 of Oceanography rock collections or from samples collected by the University of Hawai'i's

104 human occupied vehicle (HOV) submersible Pisces V reconnaissance survey (2003 and 2007) of

105 the new monument. Supplementary Table 1 summarizes sample locations.

106 Samples from near the bend of the Hawaiian-Emperor chain (Yuryaku and Daikakuji)

107 were dredged by the research vessel Thomas Washington in August of 1971 during the Scripps

108 Institution of Oceanography expedition Aries VII. This expedition dredged Koko, Kimmei,

109 Yuryaku and Daikakuji Seamounts. Published data from this cruise includes ages, some major

110 and trace element data, and isotopic compositions (Davies et al., 1971; Clague et al., 1973;

111 Clague, 1974; Clague et al., 1975; Dalrymple and Clague, 1976; Clague and Dalrymple, 1989;

112 Lanphere et al., 1980; Regelous et al., 2003; Sharp and Clague, 2006).

113 Multiple expeditions by the Hawai 'i Institute of Geophysics' research vessel Ka 'imikai-O-

114 Kanaloa dredge sampled the NWHR from 1972-1984 (identified by the prefix KK- on the sample

115 name). Some of these samples have published XRF major and trace elemental analyses (Garcia et

116 al., 1987, 2015). Recently in 2003 and 2007 the Ka imikai-O-Kanaloa has been used for several 
117 NWHR sampling expeditions to Pioneer, Laysan, and Twin Banks by the Hawai'i Undersea

118 Research Laboratory (HURL). These samples are identified by the prefix P5- and were collected

119 using the submersible Pisces $V$.

120 Two sample cores were drilled at Midway Island, one on Sand Island (Sand Island hole)

121 and one in the lagoon of Midway Atoll (reef hole) in 1965 by the Hawai' $i$ Institute of Geophysics

122 at the University of Hawai' $i$ in partnership with the U.S. Geological Survey and the U.S. Office

123 of Naval Research. Samples analyzed in this study are from the reef hole, which drilled 1261 feet

124 of limestone, dolomite, marl, and volcaniclastic sedimentary rock before penetrating

125 approximately 387 feet of tholeiitic basalt (Ladd et al., 1967, 1970; Macdonald, 1969).

126 Finally, subaerial samples from Mokumananana (formerly known as Necker Island) and

127 Nīhoa Island were collected by Harmon Craig during the 1985 ALCYONE expedition of Scripps

128 Institution of Oceanography. This same cruise also dredged Nīhoa, recovering manganese crust,

129 volcaniclastic pebblestone, and volcanic rock. Strontium and neodymium isotopes on unleached

130 powders from some of these Nīhoa and Mokumananana samples were previously reported

131 (Clague, 1973; Basu and Faggart, 1996). Some of these samples were reanalyzed in this study.

\section{3. Analytical techniques and age correction}

133 Lead isotopic compositions of 22 Northwest Hawaiian Ridge basalts were analyzed at the

134 Pacific Centre for Isotopic and Geochemical Research (PCIGR) at the University of British

135 Columbia. In addition to isotopic analyses, major elements were analyzed at the University of

136 Massachusetts (Rhodes and Vollinger, 2004) and this data is reported in Garcia et al. (2015).

137 For isotopic analyses, whole rock powders were sequentially leached in $\mathrm{HCl} 6 \mathrm{~N}$ in steps

138 of 20 minutes of acid-leaching in an ultrasonic bath followed by immediate decantation before

139 fine particles have time to settle. This leaching step was repeated until the supernatant was clear, 
140 typically between 6 and 14 times. Step-wise acid leaching is a necessary procedure to remove

141 possible post-eruption alteration and/or contamination (Weis et al., 2005, 2006; Nobre Silva et al.,

142 2009, 2010). After leaching, samples were digested using $\mathrm{HF}$ and $\mathrm{HNO}_{3}$ and purified on

143 chromatographic ion exchange columns following the procedures of Fourny et al. (2016). Lead

144 isotopic ratios were determined on a Nu Plasma (Nu Instruments) MC-ICP-MS NP II 214 or Nu

1451700 that were cross-calibrated by multiple analysis of standards NIST SRM 981 and reference

146 materials of comparable composition (Kil-93 and BHVO-2). A Tl spike was added to monitor

147 internal mass fractionation (White et al., 2000) and all analyses were corrected on-line to a

$148{ }^{205} \mathrm{Tl} /{ }^{203} \mathrm{Tl}=2.3885$ (Weis et al., 2005). Analyses were then normalized off-line to NIST SRM 981

149 triple spike values of Galer and Abouchami (1998) using the sample-standard bracketing method.

150 For the duration of this study the measured ratios for the NIST SRM 981 were:

$151 \quad{ }^{208} \mathrm{~Pb} /{ }^{204} \mathrm{~Pb}=36.7188 \pm 0.0107,{ }^{207} \mathrm{~Pb} /{ }^{204} \mathrm{~Pb}=15.4983 \pm 0.0041$, and ${ }^{206} \mathrm{~Pb} /{ }^{204} \mathrm{~Pb}=16.9418 \pm 0.0028$

152 (2SD, $\mathrm{n}=102)$. On a daily basis, the standard errors on the analyses of the NIST SRM 981 are

153 smaller, in the range of $\sim 100 \mathrm{ppm}$. Mercury 204 was monitored for possible interference on mass

$154{ }^{204} \mathrm{~Pb}$ by analysis of the signal on the 202 mass. Total procedural blanks contained 3-88

155 picograms $\mathrm{Pb}$, negligible compared to the amount of $\mathrm{Pb}$ present in samples (on average $\sim 100-300$

156 nanograms $\mathrm{Pb})$.

157 Repeated analyses of U.S Geological Survey (USGS) reference material BHVO-2, a

158 Hawaiian basalt, resulted in average $\mathrm{Pb}$ isotopic compositions of ${ }^{208} \mathrm{~Pb} /{ }^{204} \mathrm{~Pb}=38.2091 \pm 0.0107$,

$159{ }^{207} \mathrm{~Pb} /{ }^{204} \mathrm{~Pb}=15.4893 \pm 0.0023$, and ${ }^{206} \mathrm{~Pb} /{ }^{204} \mathrm{~Pb}=18.6482 \pm 0.0001(2 \mathrm{SD}, \mathrm{n}=3)$, comparable to

160 recent published values (Weis et al., 2005; Fourny et al., 2016). In-house PCIGR reference

161 material Kil-93, a Hawaiian basalt from the 1993 Kîlauea eruption, resulted in average $\mathrm{Pb}$

162 isotopic compositions of ${ }^{208} \mathrm{~Pb} /{ }^{204} \mathrm{~Pb}=38.0679 \pm 0.0038,{ }^{207} \mathrm{~Pb} /{ }^{204} \mathrm{~Pb}=15.4741 \pm 0.0017$, and 
${ }^{206} \mathrm{~Pb} /{ }^{204} \mathrm{~Pb}=18.4090 \pm 0.0035$ (2SD, $\mathrm{n}=4$ ), also comparable to recent published values (Nobre

164 Silva et al., 2013a). All data compiled from the literature are normalized to NIST SRM 981

165 standard values used in this study to ensure comparability: 16.9405 for ${ }^{206} \mathrm{~Pb} /{ }^{204} \mathrm{~Pb}, 15.4963$ for

$166{ }^{207} \mathrm{~Pb} /{ }^{204} \mathrm{~Pb}$, and 36.7219 for ${ }^{208} \mathrm{~Pb} /{ }^{204} \mathrm{~Pb}$ (Weis et al., 2011).

167 Trace element concentrations (e.g. Pb, Th, U, La, and $\mathrm{Yb}$ ) of samples were measured at

168 the PCIGR using a Thermo Finnigan Element2 high resolution ICP-MS (Schudel et al., 2015;

169 Fourny et al., 2016). Powdered samples were digested in a mixture of 10:1 $\mathrm{HNO}_{3}: \mathrm{HF}$ with no

170 prior leaching. After digestion, samples were fluxed in $6 \mathrm{~N} \mathrm{HCl}$ to eliminate insoluble fluorides,

171 dried down and diluted 5000 times in a $5 \% \mathrm{HNO}_{3}-1 \% \mathrm{HF}-1 \mathrm{ppb}$ In solution, and analyzed on the

172 Element2 using the USGS basaltic standard BCR-2 for external calibration (Schudel et al., 2015;

173 Fourny et al., 2016). BHVO-2 was analyzed with all samples, and resulting values were within

174 two standard deviations of published values for all elements (Schudel et al., 2015; Fourny et al.,

175 2016). Full procedural duplicates and replicate measurements showed excellent agreement, and

176 most elements were analyzed with one relative standard deviation (RSD) of less than 5\%.

177 Radiogenic $\mathrm{Pb}$, a powerful discriminator of Loa and Kea trends, (in this paper, radiogenic

$178 \mathrm{~Pb}$ refers to $\left.{ }^{208} \mathrm{~Pb}^{*} /{ }^{206} \mathrm{~Pb}^{*}\right)$ is a measure of the time integrated $\mathrm{Th} / \mathrm{U}$ ratio of the source throughout

179 the entire history of the Earth (Galer and O'Nions, 1985; Tatsumoto et al., 1973; White, 2015). It

180 is calculated for each sample based on the equation below where the initial $\mathrm{Pb}$ isotopic values are

181 taken as the measured isotopic compositions of the Canyon Diablo troilite, assumed to be

182 representative of the initial isotopic compositions of the Earth.

$$
\frac{{ }^{208} P b^{*}}{{ }^{206} P b^{*}}=\frac{\left(\frac{{ }^{208} P b}{{ }^{204} P b}\right)_{\text {sample }}-\left(\frac{{ }^{208} P b}{{ }^{204} P b}\right)_{\text {initial }}}{\left(\frac{{ }^{206} P b}{{ }^{204} P b}\right)_{\text {sample }}-\left(\frac{{ }^{206} P b}{{ }^{204} P b}\right)_{\text {initial }}}
$$




$$
\text { where }\left(\frac{{ }^{208} \mathrm{~Pb}}{{ }^{204} \mathrm{~Pb}}\right)_{\text {initial }}=29.476 \quad\left(\frac{{ }^{206} \mathrm{~Pb}}{{ }^{204} \mathrm{~Pb}}\right)_{\text {initial }}=9.307
$$

Identifying differences in $\mathrm{Pb}$ isotopic ratios for rocks that are older than a few million

185 years is contingent upon the accurate and precise determination of initial isotopic ratios of $\mathrm{Pb}$ at 186 the time of eruption. Samples in this study span an age range from 8.5 to $\sim 47 \mathrm{Ma}$ (O'Connor et 187 al., 2013; Dalrymple et al., 1974, 1981; Garcia et al., 1987, 2010). Age correction of measured 188 isotope ratios is necessary in the older NWHR samples to account for in situ radiogenic decay of 189 parent to daughter isotopes since eruption. This correction is very small for young samples, but 190 for samples older than $\sim 15-20$ Ma age corrections of measured isotopic ratios are outside the 191 range of analytical error. The accuracy of this correction is also affected by the fact that both 192 subaerial weathering while the volcano was above sea level and seawater alteration once the 193 volcano subsided below sea level might have altered many of these samples, disturbing the 194 magmatic elemental concentrations and ratios. All NWHR volcanoes older than Midway Island 195 are currently below sea level. Loss-on-ignition of analyzed NWHR rocks ranges from less than 1 196 to 5 weight percent (Garcia et al., 2015), certainly not as altered as some samples analyzed from 197 the Emperor Seamounts (Regelous et al., 2003), but greater than what is considered fresh for a 198 Hawaiian basalt (LOI <3 weight percent; Garcia et al., 2015). In the $\mathrm{U}-\mathrm{Th}-\mathrm{Pb}$ decay systems, $\mathrm{U}$ and $\mathrm{Pb}$ are the most sensitive to secondary alteration and 200 as a result, the elemental concentrations measured in unleached powders are not always 201 representative of the primary magmatic concentrations. The degree to which samples have been 202 compromised by alteration can be assessed using element ratios that vary very little in oceanic 203 island basalts (OIBs). Useful ratios for the $\mathrm{U}-\mathrm{Th}-\mathrm{Pb}$ systems include $\mathrm{Ce} / \mathrm{Pb}(25 \pm 5), \mathrm{Nb} / \mathrm{U}(47 \pm$ 204 10), and Th/U (4 \pm 0.5; Hofmann et al., 1986; O’Nions and McKenzie, 1993; Nobre Silva et al., 
2013a). Here we use the Th/U ratio of samples to estimate primary U concentrations in unleached

206 sample powders following the method of Nobre Silva et al. (2013a) that considers Th immobile

207 during basaltic weathering and used the $\mathrm{Th} / \mathrm{U}$ ratio to assess $\mathrm{U}$ loss or gain. The average $\mathrm{Th} / \mathrm{U}$

208 ratio of Hawaiian shield lavas is $\sim 3(n=294)$, not significantly different from NWHR lavas or

209 OIBs globally (O’Nions and McKenzie, 1993; Nobre Silva et al., 2013a). Correcting measured U

210 concentration values back to a $\mathrm{Th} / \mathrm{U}$ of 3 (assuming only $\mathrm{U}$ has been gained or removed by

211 alteration) provides a robust estimation of magmatic U concentrations and a better approximation

212 of initial $\mathrm{Pb}$ isotopic ratios. In addition to using this method on our new isotopic data, we also re-

213 correct Emperor Seamount literature data using this technique for overall comparability of the

214 dataset. Previous researchers addressed secondary alteration elemental mobility by measuring

215 concentrations of leached sample powders for age correction purposes (Regelous et al., 2003;

216 Huang et al., 2005; Shafer et al., 2005). However, this method assumes that secondary alteration

217 was a closed system and did not fractionate elements between the primary and secondary phases

218 (Staudigel et al., 1996). More recently it has been shown that acid leaching differentially removes

219 some elements (Nobre Silva et al., 2009, 2010; Hanano et al., 2009). The impact of elemental

220 mobility during alteration is particularly well displayed by the oldest sampled Emperor Seamount,

221 Meiji ( 85 Ma), which is significantly altered and has proven notoriously problematic for

222 accurate age correction (Regelous et al., 2003; Frey et al., 2005; Huang et al., 2005). Using the

$223 \mathrm{U} / \mathrm{Th}$ estimation method described here to age-correct previous data provides age-correct $\mathrm{Pb}$

224 isotopic compositions that are more coherent than previously reported for Emperor Seamount

225 data. To illustrate, radiogenic $\mathrm{Pb}$ of Meiji ranges from 0.88-0.92 after applying our correction

226 method versus unrealistically high 0.96-1.01 in published data (Regelous et al., 2003). For

227 comparison, average ${ }^{208} \mathrm{~Pb}^{*} /{ }^{206} \mathrm{~Pb}^{*}$ of the most enriched Hawaiian volcano Ko'olau is $0.96 \pm 0.02$ 
228 ( $n=36)$ while East Pacific Rise MORB is $0.92 \pm 0.03(n=146)$. Because Meiji erupted under the

229 thinnest lithosphere of any Hawaiian volcano with high degrees of melting near a mid-ocean

230 ridge, it is highly unlikely that lavas have such highly radiogenic $\mathrm{Pb}$ isotopic compositions,

231 overlapping with Ko'olau Makapu'u compositions that are only observed on O`ahu (Keller et al.,

232 2000; Regelous et al., 2003; Frey et al., 2005). Also, the use of measured elemental

233 concentrations on leached sample powders of such altered rocks tends to over-correct measured

234 isotopic ratios and is not the adequate solution to correct for in situ decay of radioactive parents

235 (Frey et al., 2005). Finally, the robustness of our age correction procedure is illustrated in Figure

$236 \mathrm{~S}$ 1, which shows ${ }^{207} \mathrm{~Pb} /{ }^{204} \mathrm{~Pb}$ versus ${ }^{206} \mathrm{~Pb} /{ }^{204} \mathrm{~Pb}$ of the NWHR, Emperor Seamounts, and major

237 Hawaiian Island volcanoes (see supp. info. references for data sources in Figures 2, 3, S1, and

$238 \mathrm{~S} 2$ ). The limited range of ${ }^{207} \mathrm{~Pb} /{ }^{204} \mathrm{~Pb}$ of NWHR lavas that overlaps with non-age corrected young

239 Hawaiian Island data supports the robustness of our leaching and age-correction procedure to

240 recover accurate initial isotopic ratios of plume sourced basalts.

241 4. Results

Extreme Ko'olau Makapu'u-type $\mathrm{Pb}$ isotopic signatures were found only once along the

243 NWHR; Daikakuji Seamount has the most unradiogenic ${ }^{206} \mathrm{~Pb} /{ }^{204} \mathrm{~Pb},{ }^{207} \mathrm{~Pb} /{ }^{204} \mathrm{~Pb}$, and ${ }^{208} \mathrm{~Pb} /{ }^{204} \mathrm{~Pb}$

244 among NWHR lavas (17.869, 15.418, and 37.809, respectively; Fig. 2a; Table 1). The most

245 radiogenic lead isotopic compositions are observed for lavas from Midway in ${ }^{206} \mathrm{~Pb} /{ }^{204} \mathrm{~Pb}(18.669)$

246 and Pioneer Seamount in ${ }^{207} \mathrm{~Pb} /{ }^{204} \mathrm{~Pb}$ (15.493) and ${ }^{208} \mathrm{~Pb} /{ }^{204} \mathrm{~Pb}$ (38.206) (Fig. 2a). Samples from

247 Daikakuji, Mokumanamana, and West Nīhoa plot on the Loa side of the Loa-Kea divide line in

$248{ }^{208} \mathrm{~Pb} /{ }^{204} \mathrm{~Pb}-{ }^{206} \mathrm{~Pb} /{ }^{204} \mathrm{~Pb}$ isotopic space (Fig. 2a). After Daikakuji, there are no Loa-like

249 compositions until the youngest section at Mokumanamana and Nīhoa (less than 11 Ma;

250 Dalrymple et al., 1974). The Pb isotopic composition of Nīhoa lavas span about two-thirds of the 
251 entire range of ${ }^{208} \mathrm{~Pb} /{ }^{204} \mathrm{~Pb}$ present in young Hawaiian lavas $(37.913-38.144)$ and define a trend 252 that crosses the Loa-Kea divide (Fig. 2a), an intriguing hint that Nīhoa may be a composite island 253 with two volcanic centers of distinct compositions. Further work is needed to explore this 254 possibility.

255 The majority of NWHR lavas are distinctly Kea-like in their geochemical affinity (Fig. 2a;

256 Table 1). These lavas span nearly the entire range in ${ }^{208} \mathrm{~Pb} /{ }^{206} \mathrm{~Pb}$ and ${ }^{207} \mathrm{~Pb} /{ }^{206} \mathrm{~Pb}$ observed in Kea257 trend shield lavas on the Hawaiian Islands (Fig. 2b). The variation in Pb isotopic composition can 258 be explained by mixing 40-91\% of the Kea end-member component with an isotopically depleted 259 plume source such as the Depleted Makapu'u (DMK) component, one of the four end-member 260 components identified in Hawaiian lavas (i.e. Kea, EMK, DMK, Lō'ihi; Tanaka et al., 2002, 261 2008; see Fig. 2b). All of the Hawaiian geochemical components are thought to be intrinsic to the 262 plume and sourced from the deep mantle (Tanaka et al., 2002, 2008; Regelous et al., 2003; Weis 263 et al., 2011).

Some NHWR lavas (Daikakuji and Nīhoa) have Loa-like Pb isotopic compositions whose 265 range of variations may be explained by mixing 35-40\% of the Enriched Makapu'u (EMK) with 266 the Kea component (Fig. 2b; Tanaka et al., 2002). The Enriched Makapu'u end member, 267 proposed to contain mafic recycled crustal material (Tanaka et al., 2008), is more fusible and thus 268 likely to be observed under lower melting conditions (Fig. 2a inset; Pertermann and Hirschmann, 269 2003). High primitive-mantle normalized $\mathrm{La} / \mathrm{Yb}_{\mathrm{PM}}$ values (>5) correspond to lower degrees of 270 partial melting because La is more incompatible and highly sensitive to degree of partial melting 271 whereas $\mathrm{Yb}$ is nearly constant in Hawaiian lavas due to melting in the garnet stability field 272 (Hofmann and Farnetani, 2013). This is not an effect of regional changes in lithospheric thickness 273 because the NWHR erupted on oceanic lithosphere older than 70 Ma (White, 1993; Caplan- 
274 Auerbach et al., 2002), which is the age when oceanic lithospheric thickness reaches a stable

275 maximum of $\sim 90 \mathrm{~km}$ based on the plate tectonic model (Parsons and Sclater, 1977). The isolated

276 occurrence of enriched Loa-type $\mathrm{Pb}$ isotopic composition at Daikakuji suggests it is not related to

277 a first arrival of a sustained Loa component in the Hawaiian mantle plume as previously proposed

278 (Garcia et al., 2015). Daikakuji is characterized by anomalously high La/Yb $\mathrm{P}_{\mathrm{PM}}$ ratios compared to

279 Hawaiian shield basalts ( $\mathrm{La} / \mathrm{Yb}_{\mathrm{PM}}$ of 6.9-8.5 for Daikakuji lavas versus 2.0-5.1 for Mauna Loa

280 and Mauna Kea lavas; primitive mantle values from McDonough and Sun, 1995). Many NWHR

281 Loa and Kea-type lavas are high in $\mathrm{La} / \mathrm{Yb}_{\mathrm{PM}}$ compared to Hawaiian island and Emperor

282 Seamount shield lavas and may reflect lower degrees of melting, at least locally. Previous authors

283 argued that Emperor Seamount lavas are characterized by higher ${ }^{206} \mathrm{~Pb} /{ }^{204} \mathrm{~Pb}$ at a given ${ }^{208} \mathrm{~Pb} /{ }^{204} \mathrm{~Pb}$

284 because they were initially erupted onto thin, young crust that grew progressively thicker with

285 time and increasing distance from the Pacific-Kula spreading ridge (Keller et al., 2000; Regelous

286 et al., 2003). The geochemistry of Emperor Seamount lavas reflects this thickening lid effect,

287 with a possible contribution from a depleted MORB mantle source for the oldest seamounts,

288 Detroit and Meiji (Fig. 2; Keller et al., 2000; Regelous et al., 2003; Whittaker et al., 2015).

289 Conversely, all NWHR volcanoes erupted onto oceanic crust older than 70 Ma without

290 interaction with a nearby spreading ridge (supplementary fig. S2; White, 1993; Whittaker et al.,

291 2015). Thus the depleted component (DMK) involved in mixing with the Kea component to

292 produce NWHR Kea-type lavas is different from the one involved in the formation of the

293 Emperor Seamounts.

Lead isotopes generally vary systematically in time and space along the NWHR (Fig. 3).

295 They become more radiogenic (i.e. increase in ${ }^{208} \mathrm{~Pb}^{*} /{ }^{206} \mathrm{~Pb} *$ ) from the oldest to the youngest

296 volcanoes. This represents a fundamental difference from the Emperor Seamounts, which on 
average are uniformly unradiogenic. Radiogenic $\mathrm{Pb}$ correlates with the overall increase in

298 magmatic flux along the NWHR, except for Gardner and Daikakuji Seamounts, which are

299 respectively local maxima and minima of magmatic flux along the ridge (Fig. 3 inset).

300 Furthermore, volcano compositions separate into three compositional trends (Kea, Loa, and

301 Enriched Loa, Fig. 3 inset) only for the main Hawaiian Islands at a critical threshold of magmatic

302 flux $\left(\sim 4 \mathrm{~m}^{3} / \mathrm{s}\right.$ based on the most recent magmatic flux model; Wessel, 2016). NWHR volcanoes

303 do not present a clear geographical distribution as exhibited by the parallel chains of Loa and Kea

304 paired volcanoes on the Hawaiian Islands younger than O`ahu ( $\sim 3 \mathrm{Ma})$. For much of the NWHR,

305 there are only single, widely spaced volcanoes, while in other places there are as many as four

306 volcanoes abreast; thus geochemistry is the only predictor of Loa or Kea-type affinity rather than

307 the spatial positioning of NWHR volcanoes.

308 5. Discussion

\subsection{Role of the Lithosphere in Magmatic Flux and Pb Composition of NWHR Basalts}

The thickness of the lithosphere is postulated to have an effect on magmatic flux because

311 thinner, warmer lithosphere allows higher degrees of melting than thick, cold lithosphere (White,

312 1993; Keller et al., 2000; Regelous et al., 2003; Niu et al., 2011). Higher degrees of melting

313 results in lavas that are less enriched in incompatible elements with lower radiogenic $\mathrm{Pb}$ due to

314 dilution of the signature of small, enriched heterogeneities by productive melting of large

315 volumes of peridotite (Pertermann and Hirschmann, 2003; Garcia et al., 2010). Thus if

316 lithospheric thickness did exert a primary control over magmatic flux, we would also expect it to

317 impact the erupted $\mathrm{Pb}$ isotopic signature of basalts. Along the NWHR, there is no correlation of

318 radiogenic $\mathrm{Pb}$ with lithospheric thickness (see Supp. Fig. S2), regardless of the type of

319 lithospheric thickness model employed (i.e. a half space cooling model or a plate tectonic model; 
320 Parker and Oldenberg, 1973; Parsons and Sclater, 1977). This indicates that lithospheric thickness

321 variations are not as significant as source composition changes in explaining the exponential

322 increase in magmatic flux along the NWHR. Emperor Seamount geochemistry, conversely,

323 correlates with changes in lithospheric thickness, although it is important to note that increases in

324 lithospheric thickness from the oldest to youngest Emperor Seamounts did not result in any

325 significant decrease in magmatic flux (Supp. Fig. S2; Regelous et al., 2003; Garcia et al., 2015).

326 Furthermore, both the Emperor Seamounts and all of the Hawaiian chain younger than the bend

327 exhibit the same magnitude of variation in radiogenic $\mathrm{Pb}$ : Emperor Seamounts ${ }^{208} \mathrm{~Pb}^{*} /{ }^{206} \mathrm{~Pb} *$

328 range from 0.89 at Meiji to 0.94 at Detroit, 59.4\% of total range of Hawaiian-Emperor chain;

329 younger than the bend range from ${ }^{208} \mathrm{~Pb}^{*} /{ }^{206} \mathrm{~Pb} * 0.92$ at Midway to 0.97 at Ko'olau, $59.6 \%$ of

330 total range. This corresponds to vastly different ranges of variations of lithospheric thickness

331 (Emperor Seamounts 22.4-92.2 km, 92\% of total range of Hawaiian-Emperor chain; younger than

332 the bend 89.4-98.2 km, 10\% of the total range) and magmatic flux (Emperor Seamounts $\sim 1 \%$ of

333 variation; younger than the bend $\sim 99 \%$ of variation). These results are inconsistent with the

334 hypothesis that changes in geochemical signature of erupted basalts and in magmatic flux are

335 principally controlled by lithospheric thickness.

336 Physical variations of the lithosphere such as changes in temperature and thickness

337 between the major Pacific fracture zones (e.g. Murray, Mendicino, and Molokai fracture zones;

338 Fig. 1 inset) could have an effect on magmatic flux (Van Ark and Lin, 2004; Wessel, 2016).

339 However, NWHR geochemistry does not alter across these structures and instead gradually

340 increases in radiogenic Pb across all fracture zones of the NWHR and Hawaiian Islands (Fig. 3).

341 It has also been hypothesized that variations between extensional and compressional stress in the

342 Pacific Plate by changes in absolute plate motion could have an effect on how much magma is 
343 able to pass through the lithosphere and erupt (Wessel and Kronke, 2008; O'Connor et al., 2013;

344 Wessel, 2016). Potentially, this could have impact the degree of melting along the NWHR, but

345 both the steady increase in radiogenic $\mathrm{Pb}$ and in magmatic flux along the NWHR after Midway

346 Island would require a steady transition into an increasingly tensional stress regime for the Pacific

347 Plate from $\sim 20 \mathrm{Ma}$ to the present. This is unlikely as geologic events that alter absolute plate

348 motion around the Pacific are more episodic (Wessel and Kronke, 2008). It has also been

349 hypothesized that small-scale sub-lithospheric rolls caused by sub-lithospheric convection is the

350 cause of the Loa and Kea bilateral trends on the Hawaiian Islands (Ballmer et al., 2011).

351 However, this theory breaks down along the NWHR because the entire NWHR is erupted onto

352 oceanic crust mature enough to have small-scale sub-lithospheric convection, yet there is only an

353 episodic presence of the Loa component and no evidence for a bilateral plume along the NWHR.

354 It is possible that smaller timescale fluctuations in magmatic flux (e.g. 1-2 and 10-15 Myr

355 variations; Wessel, 2016; see Fig. 3) could be caused by variations in plume dynamics (e.g.

356 solitary waves; Whitehead and Helfrich, 1988; Ito, 2001) possibly generated by pulses of core-

357 mantle heat transfer (Mjelde et al., 2010). However, our sample resolution is not fine enough to

358 assess the potential correlation of geochemistry with such a short periodicity. The current

359 resolution of sampling does not show any correlation of radiogenic $\mathrm{Pb}$ with these small

360 fluctuations in flux, while there is a clear general trend of increasing magmatic flux. The same

361 limitation in sampling resolution applies to assess the possible effect of local fluctuations in the

362 thickness or stress field of the lithosphere. Below, we propose a deep mantle geodynamic

363 conceptual model that accounts for the variation of $\mathrm{Pb}$ isotopes with time along the Hawaiian-

364 Emperor chain and also explains geophysical changes in magmatic flux.

365 5.2 Role of the LLSVP in Magmatic Flux and Pb Isotopic Composition of NWHR Basalts 
The arrangement of compositionally heterogeneous lower mantle structures in the source region of deep-sourced plumes is thought to control the geochemistry of erupted oceanic island basalts (Farnetani and Hofmann, 2009; Weis et al., 2011). The Hawaiian mantle plume is located above an ultra-low velocity zone (ULVZ) at the edge of the large low shear velocity province

370 (LLSVP) located in the Pacific lower mantle near the core-mantle boundary (McNamara et al.,

371 2010; Cottaar and Romanowicz, 2012; French and Romanowicz, 2015; Garnero et al., 2016).

372 LLSVPs are thousands of kilometers wide, sharp-sided ( 400-600 km thick), chemically

373 heterogeneous, long-lived piles of anomalously seismically slow material in the lower mantle

374 below the Pacific Ocean and African continent (Garnero et al., 2016). ULVZs are much smaller,

375 denser features $(\sim 10 \mathrm{~km}$ thick and <100 km across, except underneath Hawai' $i$ where it is $\sim 900$

376 km across; Cottaar and Romanowicz, 2012) that may contain partial melts (Jellinek and Manga,

377 2004; McNamara et al., 2010; Garnero et al., 2016). Mantle plumes may drift across or around

378 these lower mantle structures on long timescales triggered by dynamic re-equilibration from the 379 arrival of subducting slabs (McNamara et al., 2010; Bower et al., 2013; Garnero et al., 2016;

380 Hassan et al., 2016). It has also been suggested that the enriched geochemical compositions of 381 some oceanic island basalts originate from these lower mantle reservoirs, which are either the 382 remnants of a primordial magma ocean or accumulations of subduction recycled crustal material 383 (Weis et al., 2011; Li et al., 2015; Garnero et al., 2016). ULVZ material is denser than 384 surrounding peridotitic mantle and only small amounts are likely entrained by plumes in addition 385 to LLSVP material (Jellinek and Manga, 2004; McNamara et al., 2010; Weis et al., 2011; Cottaar 386 and Romanowicz, 2012; Li et al., 2015). Increasing radiogenic Pb along the NWHR suggests an 387 increasing contribution from these enriched sources with time. Dynamic changes in the lower 388 mantle may control the amounts of LLSVP, ULVZ, and ambient mantle entrained into the 
Hawaiian mantle plume. We propose that the Hawaiian plume initiated close to the margin of the

390 Pacific LLSVP, sampling only the Kea component (the deep Pacific mantle) during Emperor

391 Seamount formation, then drifted up and anchored at the edge of the Pacific LLSVP to entrain

392 enriched material in increasing quantities as the NWHR formed (Fig. 4).

394 sources over its 85 million year lifetime. Plumes worldwide migrate slowly through the mantle at 395 velocities of $\sim 1.1 \mathrm{~cm} /$ year (Davies and Davies, 2009), an observation supported by the better fit 396 of dynamic models with moving-source plumes than fixed-source plumes to global seismic 397 tomographic models (Boschi et al., 2007). The lower mantle has been moving south at a rate of 1$3984 \mathrm{~cm} /$ year (seismic anisotropy studies; Walker et al., 2011) or 1-2 mm/year (plume experiments; 399 Davaille et al., 2003). Dynamic global mantle convection and hotspot track reconstructions of the 400 last 230 Myr identified south-southeast flow with varied strength for the base of Hawaiian mantle 401 plume towards the central Pacific (Steinberger, 2000, 2004; Davaille et al., 2003; Burke and 402 Torsvik, 2004; Hassan et al., 2016). Assuming the base of the Hawaiian mantle plume was 403 advected in that flow at the lowest rate $(\sim 1 \mathrm{~mm} /$ year; Steinberger, 2000, 2004; Garnero et al., 404 2016; Hassan et al., 2016), it could have drifted 80 kilometers in the lower mantle. Plume 405 movement tends to be episodic (Davies and Davies, 2009; Hassan et al., 2015) while still allowing 406 the sampling of different lower mantle domains. Dynamic models and plume experiments have 407 established that plumes anchor on topographic features such as ULVZs or LLSVP ridges (Jellinek 408 and Manga, 2004; Steinberger et al., 2004; Boschi et al., 2007; McNamara et al., 2010; Bower et 409 al., 2013; French and Romanowicz, 2015). Finally, the mass conservation law requires 410 compensation of upper mantle wind by equal and opposite movement in the lower mantle 411 (Steinberger, 2000; Farnetani and Hofmann, 2009), likely resulting in plume drift. 
413 along the rim of LLSVP; this is where P-waves begin to slow, many mantle plumes are generated, 414 and ULVZs are detected (Jellinek and Manga, 2004; Kumagai et al., 2008; Davies and Davies, 415 2009; McNamara et al., 2010; Cottaar and Romanowicz, 2012; Hassan et al., 2015). The northern 416 edge of the Pacific LLSVP underneath Hawai' $\mathrm{i}$ is not steep sided, but has a $25-35^{\circ}$ north-

417 northwest-facing gentle slope to a topographic high $\sim 450 \mathrm{~km}$ above the core mantle boundary (He 418 and Wen, 2012; Frost and Rost, 2014; Zhao et al., 2015). The Hawaiian mantle plume initiated 419 slightly to the north of the present plume location where the highest temperatures occur (Fig. 4b). 420 After formation, the flow of ambient mantle south up the edge of the LLSVP would push the 421 plume to the most dynamically stable place, anchored at an LLSVP ridge above a ULVZ (Fig. 4c, 422 4d; Davaille et al., 2003; Jellinek and Manga, 2004; Zhao et al., 2015; Garnero et al., 2016). 423 During this time, the Hawaiian mantle plume sampled peridotitic mantle from outside the LLSVP 424 (Sobolev et al., 2005; Tanaka et al., 2008), which corresponds to the Kea component, also present 425 in nearly all Pacific oceanic plateaus (e.g. Ontong Java, Shatsky Rise, and Wrangellia) and 426 oceanic islands (Nobre Silva et al., 2013b). It is also the same composition as prevalent mantle 427 (PREMA), an ubiquitous component in the mantle where oceanic island basalt isotope arrays 428 converge (White, 2015 and references therein). In addition, the dominance of this material during 429 the initiation of the Hawaii mantle plume (e.g. Emperor Seamounts) would account for the low 430 magmatic flux during this time because peridotite is less productive than enriched, mafic 431 lithologies (Pertermann and Hirschmann, 2003; Van Ark and Lin, 2004; Vidal and Bonneville, 432 2004). This is in agreement with the theoretical flux for a fully peridotitic Hawaiian plume $(\sim 3.5$ $433 \mathrm{~m}^{3} \mathrm{~s}^{-1}$ for peridotite only, rather than the observed $8 \mathrm{~m}^{3} \mathrm{~s}^{-1}$ ) and within the range of other Pacific 434 plume fluxes (Courtillot et al., 2003; Sobolev et al., 2005). Conversely, if the Hawaiian plume 
435

was both generated and fixed on the Pacific LLSVP, we would expect to observe Loa compositions in lavas from the entirety of the Hawaiian-Emperor chain. Although it is possible that the participation of the Loa component was concealed in Emperor Seamount lavas by dilution from voluminous melting beneath young, thin lithosphere (supplementary figure S2; Regelous et al., 2003; Hofmann and Farnetani, 2013), we would then expect the Emperor Seamount data to exhibit mixing relationships that include the Loa enriched end member (EMK), which is not observed (Figure 2b).

After the plume was anchored on a LLSVP ridge above the ULVZ, it entrains initially small amounts of enriched material from the LLSVP and/or ULVZ (Fig. 4d). Incorporation of increasing amounts of this material in NWHR volcanoes gradually elevates radiogenic $\mathrm{Pb}$ (Fig. 3), changes the slope of magmatic flux growth (Wessel, 2016; Van Ark and Lin, 2004; Vidal and Bonneville, 2004), and accelerates the volcanic propagation rate (O'Connor et al., 2013). These changes all commenced $\sim 20 \mathrm{Myr}$ after the bend around Midway Island. Assuming a 15-25 Myr mantle plume transit time, this enriched material was entrained around the time of the bend (Hassan et al., 2015; 2016). Plate reconstruction studies have found that absolute plate motion change was likely $4-31^{\circ}$ in the Pacific around the time of the bend (Steinberger et al., 2004; Tarduno et al., 2009; Wright et al., 2015), not enough to account for the $\sim 120^{\circ}$ change in bearing of the Hawaiian-Emperor chain at the bend (i.e. a $\sim 60^{\circ}$ change in absolute Pacific plate motion; Hassan et al., 2016; Tarduno et al., 2009). Previous studies hypothesized that interaction of the Hawaiian mantle plume with the Kula-Pacific mid-ocean ridge around $~ 85$ Ma tilted the plume drastically. With both increasing distance from and waning in spreading rate of the ridge, the plume moved back to a more vertical position, resulting in hotspot motion (Tarduno et al., 2009). This documented plume movement in the upper mantle coupled with the hypothesized southward 
458 plume motion in the lower mantle stabilized around the time of the bend and likely contributed to

459 the sharpness of the bend and to the transition in Hawaiian plume geochemical signature

460 (Steinberger, 2000; 2004; Tarduno et al., 2009; Hassan et al., 2016).

461 We speculate that the longer the plume is fixed on a ridge of the LLSVP, the more

462 sustained is the sampling of LLSVP and/or ULVZ enriched material, resulting in both higher

463 radiogenic $\mathrm{Pb}$ and magmatic flux as Loa-type source lithologies are more fusible pyroxenites and 464 eclogites (Pertermann and Hirschmann, 2003; Sobolev et al., 2005). The bilateral Kea-Loa trends

465 of the Hawaiian Islands appear once the plume has been anchored on the Pacific LLSVP for 466 enough time to provide a sustained supply of both enriched material on the southwest edge of the 467 plume (Loa) and ambient Pacific mantle on the northeast side of the plume (Kea; Fig. 4e;

468 Farnetani and Hofmann, 2009; Weis et al., 2011; Nobre Silva et al., 2013b). The ephemeral 469 presence of the Loa composition along the NWHR suggests that a simple concentric or bilateral 470 zonation of the Hawaiian mantle plume is overly simplistic, as concluded for the Hawaiian

471 Islands (Xu et al., 2014). The isolated and highly radiogenic lavas erupted at Daikakuji volcano 472 right after the Hawaiian-Emperor bend may be explained by a combination of unique melting 473 conditions of this volcano coupled with the presence of a small mantle heterogeneity. Daikakuji 474 exhibits the coldest mantle potential temperature of any studied Hawaiian volcano (i.e. $1335 \pm 26$ $475{ }^{\circ} \mathrm{C}$, versus the current range of estimated mantle potential temperatures on the Island of Hawai ${ }^{\circ} \mathrm{i}$ 476 1632-1690 ${ }^{\circ} \mathrm{C}$; Tree, 2016), resulting in low degrees of melting. This is also supported by the fact 477 that Daikakuji has the highest $(\mathrm{La} / \mathrm{Yb})_{\mathrm{PM}}$ of the entire Hawaiian-Emperor chain (Fig. 2a inset).

478 These extremely low degrees of melting allowed the signature of a finite and isolated 479 heterogeneity to be expressed for a short period of time. The mantle has been shown to be 480 heterogeneous on scales varying between melt inclusion scale (Ren et al., 2005) to the hundreds 
481 of kilometers scale (Garnero et al., 2016), and periodic entrainment of plum-pudding type

482 heterogeneities is not unexpected.

\section{6. Conclusion}

New high-precision $\mathrm{Pb}$ isotopic data closes the $2700 \mathrm{~km}$ ( 42 Myr) gap in the Hawaiianmillion years after the bend. During this period, the flux of the Hawaiian plume, mantle potential temperature, and volcanic propagation rate all increased. The correlation of radiogenic $\mathrm{Pb}$ with magmatic flux indicates that all of these changes are related, and we suggest may be triggered by the movement of the deep source of the Hawaiian plume through different lower mantle compositional domains, from sampling dominantly ambient Pacific mantle outside of the LLSVP

491 to entraining enriched material from the ULVZ and Pacific LLSVP. Mounting geochemical and 492 geodynamical data on oceanic islands and chains suggest the lower mantle is both dynamic and 493 compositionally heterogeneous in space and time. Long-lived mantle plumes such as Hawai'i

494 provide a window into this fundamental Earth reservoir and future integrated geochemical and 495 geophysical studies of long island chains will provide the key insight needed to decipher the 496 relationship between geochemical components and geophysical anomalies in the deep mantle.

\section{Acknowledgements}

498 Our thanks go to Kathy Gordon and Liyan Xing for assistance analyzing Pb isotopic 499 compositions and to Jonathan Tree for NWHR sample cataloguing and rock preparation. We are 500 also grateful to the Ocean Drilling Program, John Smith of the Hawai'i Undersea Research

501 Laboratory (HURL), and Alexandra Hangsterfer of Scripps Institution of Oceanography for 502 samples analyzed in this study. This manuscript benefited greatly from reviews by Drs. Matthew

503 Jackson and Marcel Regelous as well as discussions with Diane Hanano, Nicole Williamson, 
Catherine Armstrong, Laura Bilenker, Mark Jellinek, Emily Mullen, and James Scoates. This

Grant to D. Weis, and a University of British Columbia Four Year Fellowship to L. Harrison.

507

508

\section{References}

Abouchami, W., Hofmann, A.W., Galer, S.J.G., Frey, F.A., Eisele, J., Feigenson, M., 2005. Lead isotopes reveal bilateral asymmetry and vertical continuity in the Hawaiian mantle plume. Nature 434, 851-856.

Ballmer, M.D., Ito, G., van Hunen, J., Tackley, P.J., 2011. Spatio and temporal variability in Hawaiian hotspot volcanism induced by small-scale convection. Nat. Geosci. 4, 457-460.

Bargar, K.E., Jackson, E.D. 1974. Calculated volumes of individual shield volcanoes along the Hawaiian-Emperor chain. J. Res. U.S. Geol. Surv. 2(5), 545-550.

Basu, A.R., Faggart, B.E.F., 1996. Temporal isotopic variations in the Hawaiian Mantle Plume: The Lanai anomaly, the Molokai fracture zone and a seawater-altered lithospheric component in Hawaiian volcanism. In: Basu, A., Hart, S. (Eds.), Earth Processes: Reading the Isotopic Code. Geophysical Monograph Series Vol. 95, American Geophysical Union, pp. 149-159.

Boschi, L., Becker, T.W., Steinberger, B., 2007. Mantle plumes: Dynamic models and seismic images. Geochem. Geophys. Geosyst. 8, 1-20.

Bower, D.J., Gurnis, M., Seton, M., 2013. Lower mantle structure from paleogeographically constrained dynamic Earth models. Geochem. Geophys. Geosyst. 14, 44-63.

Burke, K., Torsvik, T.H., 2004. Derivation of large igneous provinces of the past 200 million years from long-term heterogeneities in the deep mantle. Earth Planet. Sci. Lett. 227, 531-538.

Caplan-Auerbach, J., Duennebier, F., Ito, G., 2002. Origin and intraplate volcanoes from guyot heights and oceanic paleodepth. J. Geophys. Res. 105, 2679-2697.

Clague, D., Dalrymple, G.B., Greene, H.G., Wald, D., Kono, M., Kroenke, L.W., 1973. Bathymetry of the Emperor Seamounts. In: Jackson, E.D. et al. (Eds.) Initial reports of the deep sea drilling project, Vol. 55. Deep Sea Drilling Project, pp. 845-849.

Clague, D.A., 1974. The Hawaiian-Emperor Seamount chain: Its origin, petrology, and implications for plate tectonics, Ph.D. Thesis, University of California, San Diego, 319 p.

Clague, D.A., Dalrymple, G.B., Moberly, R., 1975. Petrography and K-Ar ages of dredged volcanic rocks from the Western Hawaiian Ridge and the Southern Emperor Seamount chain. Geol. Soc. Am. Bull. 86, 991-998.

Clague, D., Dalrymple, B., 1989. The Hawaiian-Emperor Volcanic chain part I geologic evolution. In: Decker, R.W., Wright, T.L., Stauffer, P.H. (Eds.), Volcanism in Hawaii: Papers 
to commemorate the $75^{\text {th }}$ anniversary of the founding of the Hawaiian Volcano Observatory.

Cottaar, S., Romanowicz, B., 2012. An unusually large ULVZ at the base of the mantle near Hawaii. Earth Planet. Sci. Lett. 355-356, 213-222.

Courtillot, V., Davaille, A., Besse, J., Stock, J., 2003. Three distinct types of hotspots in the

Dalrymple, G.B., Lanphere, M.A., Jackson, E.D., 1974. Contributions to the petrography and geochronology of the volcanic rocks from the leeward Hawaiian Islands. Geol. Soc. Am. Bull. $85,1-12$.

Dalrymple, G.B., Clague, D.A., 1976. Age of the Hawaiian-Emperor bend. Earth Planet. Sci. Lett. 31, 313-329.

Dalrymple, G.B., Clague, D., Lanphere, M.A., 1977. Revised age for Midway Volcano, Hawaiian volcanic chain. Earth Planet. Sci. Lett. 37, 107-116.

Dalrymple, G.B., Clague, D.A., Garcia, M.O., Bright, S.W., 1981. Petrology and K-Ar ages of dredged samples from Laysan Island and Northampton Bank volcanoes, Hawaiian Ridge, and evolution of the Hawaiian-Emperor chain: Summary. Geol. Soc. Am. Bull. Part 1. 92, 315318.

Davaille, A., Le Bars, M., Carbonne, C., 2003. Thermal convection in a heterogeneous mantle. C.R. Geosci. 335, 141-156.

Davies, T.A., Clague, D.A., Wilde, P., 1971. Preliminary report on Leg VII of ARIES Expedition: geological investigations in the western North Pacific, July-August, 1971. S.I.O. Ref. Ser. 71-27, 1-23.

Davies, D.R., Davies, J.H., 2009. Thermally-driven mantle plumes reconcile multiple hot-spot observations. Earth Planet. Sci. Lett. 278, 50-54.

Farnetani, C.G., Hofmann, A.W., 2009. Dynamics and internal structure of a lower mantle plume conduit. Earth Planet. Sci. Lett. 282, 314-322.

Fourny, A., Weis, D., Scoates, J.S., 2016. Comprehensive Pb-Sr-Nd-Hf isotopic, trace element, and mineralogical characterization of mafic to ultramafic rock reference materials. Geochem. Geophys. Geosyst. 17(3), 739-773.

French, S.W., Romanowicz, B., 2015. Broad plumes rooted at the base of the Earth's mantle beneath major hotspots. Nature 525, 95-99.

Frey, F.A., Huang, S., Blichert-Toft, J., Regelous, M., Boyet, M., 2005. Origin of depleted components in basalt related to the Hawaiian hot spot: evidence from isotopic and incompatible element ratios. Geochem. Geophys. Geosyst. 6, Q02L07.

Frost, D.A., Rost, S., 2014. The P-wave boundary of the large-low shear velocity province beneath the Pacific. Earth Planet. Sci. Lett. 403, 380-392. 
Galer, S.J.G., O’Nions, R.K., 1985. Residence time of thorium, uranium and lead in the mantle with implications for mantle convection. Nature. 316, 778-782.

Galer, S.J.G., Abouchami, W., 1998. Practical application of $\mathrm{Pb}$ triple spiking for correction of instrumental mass discrimination. Min. Mag. 62A, 491-492.

Garcia, M.O., Grooms, D.G., Naughton, J. J., 1987. Petrology and geochronology of volcanic rocks from seamounts along and near the Hawaiian Ridge: Implications for propagation rate of the ridge. Lithos 20, 323-336.

Garcia, M.O., Swinnard, L., Weis, D., Greene, A.R., Tagami, T., Sano, H., Gandy, C. E., 2010. Petrology, geochemistry, and geochronology of Kaua'i lavas over 4.5 Myr: implications for the origin of rejuvenated volcanism and the evolution of the Hawaiian Plume, J. Petrol. 51, 1507-1540.

Garcia, M.O., Smith, J.R., Tree, J.P., Weis, D., Harrison, L., Jicha, B.R., 2015. Petrology, geochemistry, and ages of lavas from the Northwest Hawaiian Ridge volcanoes. In: Neal, C.R., Sager, W.W., Sano, T., Erba, E. (Eds.). The Origin, Evolution, and Environmental Impact of Oceanic Large Igneous Provinces. Geological Society Special Paper Vol. 511, Geological Society of America, Inc., pp. 1-26.

Garnero, E.J., McNamara, A.K., Shim, S.-H., 2016. Continent-sized anomalous zones with low seismic velocity at the base of the Earth's mantle. Nat. Geosci., 9, 481-489.

Hanano, D., Scoates, J.S., Weis, D., 2009. Alteration mineralogy and the effect of acid-leaching on the Pb-isotope systematics of ocean-island basalts. Am. Mineral. 94, 17-26.

Hanano, D., Weis, D., Scoates, J.S., Aciego, S., De Paolo, D.J., 2010. Horizontal and vertical zoning of heterogeneities in the Hawaiian mantle plume from the geochemistry of consecutive postshield volcano pairs: Kohala-Mahukona and Mauna Kea-Hualalai. Geochem. Geophys. Geosyst. 11, Q01004.

Hassan, R., Müller, R.D., Gurnis, M., Williams, S.E., Flament, N., 2016. A rapid burst in hotspot motion through the interaction of tectonics and deep mantle flow. Nature. 533, 239-242.

Hassan, R., Flament, N., Gurnis, M., Bower, D.J., Müller, D., 2015. Provenance of plumes in global convection models. Geochem. Geophys. Geosyst. 16, 1465-1489.

He, Y., Wen, L., 2012. Geographic boundary of the 'Pacific Anomaly' and its geometry and transitional structure in the north. J. Geophys. Res. 117, B09308.

Hofmann, A.W. Jochum, K.P., Seufert, M., White, W.M., 1986. Nb and Pb in oceanic basalts: New constraints on mantle evolution. Earth Planet. Sci. Lett. 79, 33-45.

Hofmann, A.W., Farnetani, C. G., 2013. Two views of Hawaiian plume structure. Geochem. Geophys. Geosyst. 14, 5308-5322.

Huang, S., Regelous, M., Thordarson, T., Frey, F.A., 2005. Petrogenesis of lavas from Detroit Seamount: geochemical differences between Emperor Chain and Hawaiian volcanoes. Geochem. Geophys. Geosyst. 6, Q01L06. 
Ito, G., 2001. Reykjanes ' $\mathrm{V}$ '-shaped ridges originating from a pulsing and dehydrating mantle plume. Nature, 411, 681-684.

Jellinek, M., Manga, M., 2004. Links between long-lived hot spots, mantle plumes, D', and plate tectonics. Rev. Geophys. 42, RG3002.

Keller, R.A., Fisk, M., White, W.M., 2000. Isotopic evidence for Late Cretaceous plume-ridge interaction at the Hawaiian hotspot. Nature 405, 673-676.

Kumagai, I., Davaille, A., Kurita, K., Stutzmann, E., 2008. Mantle plumes: Thin, fat, successful, or failing? Constraints to explain hot spot volcanism through time and space. Geophys. Res. Lett. 35, L16301.

Ladd, H.S., Tracey, J.I., Gross, M.G., 1967. Drilling on Midway atoll, Hawaii. Science 156, 1088-1094.

Ladd, H.S., Tracey, J.I., Gross, M.G., 1970. Deep drilling on Midway atoll: Geology of the Midway area Hawaiian Islands. Geol. Sur. Prof. Pap. 680, 1-29.

Lanphere, M.A., Dalrymple, G.B., Clague, D.A., 1980. Rb-Sr systematics of basalts from the Hawaiian-Emperor volcanic chain. In: Jackson, E.D. et al. (Eds.), Initial reports of the deep sea drilling project, vol 55. Deep Sea Drilling Project, pp. 695-706.

Li, M., McNamara, A.K., Garnero, E.J., van Soest, M.C., Williams, C. D., 2015. Episodic entrainment of deep primordial mantle material into ocean island basalts. Nat. Commun. 6, 17.

Macdonald, G.A., 1969. Petrology of the Basalt Cores From Midway Atoll. Geol. Soc. Spec. Pap. 680-B, 1-17.

McDonough, W.F., Sun, S.-S., 1995. The composition of the Earth. Chem. Geol. 120, 223-253.

McNamara, A., Garnero, E., Rost, S., 2010. Tracking deep mantle reservoirs with ultra-low velocity zones. Earth Planet. Sci. Lett. 299, 1-9.

Mjelde, R., Wessel, P., Müller, R.D., 2010. Global pulsations of intraplate magmatism through the Cenozoic. Lithosphere, 2(5), 361-376.

Morgan, W.J., 1972. Deep mantle convection plumes and plate motions. Am. Assoc. of Petrol. Geol. Bull. 56(2), 203-213.

Niu, Y., Wilson, M., Humphreys, E.R., O’Hara, M.J., 2011. The origin of intra-plate ocean island basalts (OIB): the lid effect and its geodynamic implications. J. Petrol. 52, 1443-1468.

Nobre Silva, I.G., Weis, D., Barling, J., Scoates, J.S., 2009. Leaching systematics and matrix elimination for the determination of high-precision $\mathrm{Pb}$ isotope compositions of ocean island basalts. Geochem. Geophys. Geosyst. 10, Q08012.

Nobre Silva, I.G., Weis, D., Scoates, J.S., 2010. Effects of acid leaching on the Sr-Nd-Hf isotopic compositions of ocean island basalts. Geochem. Geophys. Geosyst. 11, Q09011. 
Nobre Silva, I.G., Weis, D., Scoates, J.S., 2013a. The Ninetyeast Ridge and its relation to the Kerguelen, Amsterdam, and St. Paul hotspots in the Indian Ocean. J. Petrol. 54, 1177-1210.

Nobre Silva, I.G., Weis, D., Scoates, J.S., 2013b. Isotopic systematics of the early Mauna Kea shield phase and insight into the deep mantle beneath the Pacific Ocean. Geochem. Geophys. Geosyst. 14(3), 659-676.

O’Connor, J.M., Steinberger, B., Regelous, M., Koppers, A., Wijbrans, J., Stoffers, P., Jokat, W., Garbe-Schonberg, D., 2013. Constraints on past plate and mantle motion from new ages for the Hawaiian-Emperor Seamount Chain. Geochem. Geophys. Geosyst. 14, 4564-4584.

O’Nions, R.K., McKenzie, D., 1993. Estimates of mantle thorium/uranium ratios from the Th, U, and $\mathrm{Pb}$ isotope abundances in basaltic melts. Phil. Trans. R. Soc. A. 342, 65-77.

Parker, R.L., Oldenburg, D.W., 1973. Thermal model of ocean ridges. Nature, 242, 137-139.

Parsons, B., Sclater, J.G., 1977. An analysis of the variation of ocean floor bathymetry and heat flow with age. J. Geophys. Res. 82(5), 803-827.

Pertermann, M., Hirschmann, M.M., 2003. Partial melting experiments on a MORB-like pyroxenite between 2 and $3 \mathrm{GPa}$ : Constraints on the presence of pyroxenite in basalt source regions from solidus location and melting rate. J. Geophys. Res. 108, 2125.

Regelous, M., Hofmann, A.W., Abouchami, W., Galer, S.J.G., 2003. Geochemistry of lavas from the Emperor Seamounts and the geochemical evolution of Hawaiian magmatism from 85 to 42 Ma. J. Petrol. 44, 113-140.

Ren, Z.-Y., Ingle, S., Takahashi, E., Hirano, N., Hirata, T., 2005. The chemical structure of the Hawaiian mantle plume. Nature, 436, 837-840.

Rhodes, J.M., Vollinger, M.J., 2004. Composition of basaltic lavas sampled by phase-2 of the Hawaii Scientific Drilling Project: Geochemical stratigraphy and magma types. Geochem. Geophys. Geosyst. 5, Q03G13.

Schudel, G., Lai, V., Gordon, K., Weis, D., 2015. Trace element characterization of USGS reference materials by HR-ICP-MS and Q-ICP-MS. Chem. Geol. 410, 223-236.

Shafer, J.T., Neal, C.R., Regelous, M., 2005. Petrogenesis of Hawaiian postshield lavas: Evidence from Nintoku Seamount, Emperor Seamount chain. Geochem. Geophys. Geosyst. 6, Q05L09.

Sharp, W.D., Clague, D., 2006. A. 50-Ma initiation of Hawaiian-Emperor bend records major change in Pacific plate motion. Science 313, 1281-1284.

Smith, J.R., Boston, B., Dechnik, B., Habel, S., Harrison, L., Kelley, C., Leonard, J., Lichowski, F., Luers, D., Miller, J., Orange, R., Patterson, M., Shiro, B., Taylor, J., Togia, H., Tree, J., Tucker, J., Wagner, D., Webster, J., Wright, N. 2014, An introduction to new multibeam data from the Papahanaumokuakea Marine National Monument in the Northwestern Hawaiian Islands Obtained by the R/V Falkor. Am. Geophys. Un. Abs. OS34A-06. 
Sobolev, A.V., Hofmann, A.W., Sobolev, S.V., Nikogosian, I.K., 2005. An olivine-free mantle source of Hawaiian shield basalts. Nature 434, 590-597.

Staudigel, H., Plank, T., White, B., Schmincke, H.-U. (1996). Geochemical fluxes during seafloor alteration of basaltic upper oceanic crust: DSDP Sites 417 and 418. In: Bebout, G.E., Scholl, D.W., Kirby, S.H., Platt, J.P. (Eds.), Subduction: Top to Bottom. Geophysical Monograph Series Vol. 96, American Geophysical Union, pp. 19-36.

Steinberger, B., 2000. Plumes in a convecting mantle: Models and observations for individual hotspots. J. Geophys. Res. 105, 127-152.

Steinberger, B., Sutherland, R., O’Connell, R.J., 2004. Prediction of Emperor-Hawaii seamount locations from a revised model of global plate motion and mantle flow. Nature 430, 167-173.

Tanaka, R., Nakamura, E., Takahashi, E., 2002. Geochemical Evolution of Koolau Volcano, Hawaii. In: Takahashi, E., Lipman, P.W., Garcia, M.O., Naka, J., Aramaki, S. (Eds.), Hawaiian Volcanoes: Deep Underwater Perspectives. Geophysical Monograph Series Vol. 128, American Geophysical Union, pp. 311-332.

Tanaka, R., Makishima, A., Nakamura, E., 2008. Hawaiian double volcanic chain triggered by and episodic involvement of recycled material: constraints from temporal Sr-Nd-Hf- $\mathrm{Pb}$ isotopic trend of the Loa-type volcanoes. Earth Planet. Sci. Lett. 265, 450-465.

Tarduno, J., Bunge, H.P., Sleep, N., Hansen, U., 2009. The bent Hawaiian-Emperor hotspot track: Inheriting the mantle wind. Science 324, 50-53.

Tatsumoto, M., Knight, R.J., Allegre, C.J., 1973. Time differences in the formation of meteorites as determined from the ratio of lead-207 to lead-206. Science 180(4092), 1279-1283.

Tree, J.P., 2016. Mantle potential temperatures of 4.5 to 47 Ma Hawaiian volcanoes using olivine thermometry: Implications for melt flux variations. M.Sc. Thesis. University of Hawai' $i$ at Mānoa, Honolulu, 126 p.

Van Ark, E., Lin, J., 2004. Time variation in igneous volume flux of the Hawaii-Emperor hot spot seamount chain. J. Geophys. Res. 109, B11401.

Vidal, V., Bonneville, A., 2004. Variations of the Hawaiian hot spot activity revealed by variations in the magma production rate. J. Geophys. Res. 109, B03104.

Walker, A.M., Forte, A.M., Wookey, J., Nowacki, A., Kendall, J.M., 2011. Elastic anisotropy of D" predicted from global models of mantle flow. Geochem. Geophys. Geosyst. 12, Q10006.

Weis, D., Kieffer, B., Maerschalk, C., Pretorius, W., Barling, J., 2005. High-precision Pb-Sr-Nd$\mathrm{Hf}$ isotopic characterization of USGS BHVO-1 and BHVO-2 reference materials. Geochem. Geophys. Geosyst. 6, Q02002.

Weis, D., Kieffer, B., Maerschalk, C., Barling, J., De Jong, J., Williams, G.A., Hanano, D., Pretorius, W., Mattielli, N., Scoates, J.S., Goolaerts, A., Friedman, R.M., Mahoney, J.B., 2006. High-precision isotopic characterization of USGS reference materials by TIMS and MC-ICP-MS. Geochem. Geophys. Geosyst. 7, Q08006. 
Weis, D., Garcia, M.O, Rhodes, J.M. Jellinek, M., Scoates, J.S., 2011. Role of the deep mantle in generating the compositional asymmetry of the Hawaiian mantle plume. Nat. Geosci. 4, 831838.

Wessel, P., Kroenke, L.W., 2008. Pacific absolute plate motion since 145 Ma: An assessment of the fixed hot spot hypothesis. J. Geophys. Res., 113, B06101.

Wessel, P., 2016. Regional-residual separation of bathymetry and revised estimates of Hawaii plume flux. Geophys. J. 204, 932-947.

White, R.S., 1993. Melt production rates in mantle plumes. Phil. Trans. R. Soc. Lond. A. 342, 137-153.

White, W.M., Albarède, F., Télouk, P., 2000. High-precision analysis of Pb isotope ratios by multi-collector ICP-MS. Chem. Geol. 167, 257-270.

White, W., 2015. Probing the Earth's Deep Interior Through Geochemistry. Geochem. Perspect. $4(2), 95-251$.

Whitehead, J.A., Helfrich, K.R., 1988. Wave transport of deep mantle material. Nature 336, 5961.

Whittaker, J.M., Afonso, J.C., Masterton, S., Müller, R.D., Wessel, P., Williams, S.E., Seton, M., 2015. Long-term interaction between mid-ocean ridges and mantle plumes. Nat. Geosci. 8, 479-483.

Wright, N.M., Müller, R.D., Seton, M., Williams, S.E., 2015. Revision of Paleogene plate motions in the Pacific and implications for the Hawaiian-Emperor bend. Geology 43, 422458.

Xu, G., Huang, S., Frey, F.A., Blichert-Toft, J., Abouchami, W., Clague, D.A., Cousens, B., Moore, J.G., Beeson, M.H., 2014. The distribution of geochemical heterogeneities in the source of Hawaiian shield lavas as revealed by a transect across the strike of the Loa and Kea spatial trends: East Molokai to West Molokai to Penguin Bank. Geochim. Cosmochim. Acta 132, 214-237.

Zhao, C., Garnero, E.J., McNamara, A.K., Schmerr, N., Carlson, R.W., 2015. Seismic evidence for a chemically distinct thermochemical reservoir in Earth's deep mantle beneath Hawaii. Earth Planet. Sci. Lett. 426, 143-153.

\section{Figure Captions}

\section{Figure 1. Bathymetric map of the $\sim 51$ seamounts and islands of the Northwest Hawaiian}

Ridge and sample locations. Bathymetry is 2-minute Gridded Global Relief Data ETOPO2v2 satellite altimetry dataset (U.S. Department of Commerce, National Oceanic and Atmospheric Administration, National Geophysical Data Center, 2006) and new multibeam bathymetry (Smith 
751 et al., 2014). White circles show sample locations. References for ages are in yellow superscript

752 and are as follows: 1 - O'Connor et al., 2013; 2 - Dalrymple et al., 1974; 3 - Dalrymple et al.,

753 1981; 4 - Garcia et al., 1987; 5 - Garcia et al., 2010. Inset figure is a traverse Mercator projection

754 of the Hawaiian-Emperor chain modified from Garcia et al, 2015. Dashed lines in this figure

755 indicate major Pacific fracture zones (FZ).

756 Figure 2. Pb-Pb isotopic diagrams for Northwest Hawaiian Ridge shield-stage basalts (error

757 bars are smaller than data points). a Plot of ${ }^{206} \mathrm{~Pb} /{ }^{204} \mathrm{~Pb}$ versus ${ }^{208} \mathrm{~Pb} /{ }^{204} \mathrm{~Pb}$ and $\mathbf{b}{ }^{207} \mathrm{~Pb} /{ }^{206} \mathrm{~Pb}$ versus

$758{ }^{208} \mathrm{~Pb} /{ }^{206} \mathrm{~Pb}$ (data sources in supplementary material). For reference the Loa-Kea divide line

759 (Abouchami et al., 2005) is shown in black, and the four Hawaiian end member components are

760 shown by empty white circles (KEA, DMK, EMK, and Lō'ihi; Tanaka et al., 2002). Mixing lines

761 are calculated between the KEA end member and enriched Makapu'u (EMK; blue line) and

762 depleted Makapu'u (DMK; red line). Tick marks are at intervals of 10\%. Inset to figure a shows a

763 histogram of primitive mantle normalized (McDonough and Sun, 1995) La/Yb of the Emperor

764 Seamounts (orange), Mauna Loa (blue), Mauna Kea (red), the Northwest Hawaiian Ridge

765 (yellow), and Daikakuji (purple). The black line is the average of Mauna Loa and Mauna Kea,

766 representative of average Hawaiian shield basalt $\left(\mathrm{La} / \mathrm{Yb}_{\mathrm{PM}} \approx 3.4\right)$ and the dashed line is average

767 EPR MORB $\left(\mathrm{La} / \mathrm{Yb}_{\mathrm{PM}} \approx 0.8\right)$. Inset to figure $\mathrm{b}$ gives the composition of the end members used in

768 the calculation of mixing lines (Tanaka et al., 2002). All literature data in this and following

769 figures is normalized to the same NIST SRM 981 values to ensure comparability.

770 Figure 3. Northwest Hawaiian Ridge ${ }^{208} \mathrm{~Pb}^{*} /{ }^{206} \mathrm{~Pb}^{*}$ variations with Hawaiian Plume

771 estimated volume flux (in $\mathrm{m}^{3} / \mathrm{s}$ assuming flexural compensation; Van Ark and Lin, 2004; Vidal

772 and Bonneville, 2004; Wessel, 2016). The black curve is the average flux variation with

773 uncertainty shown in red (Wessel, 2016). The flux of the Emperor Seamounts is from Van Ark 
774 and Lin (2004; green line) and Vidal and Bonneville (2004; purple line) or not calculated

775 (Wessel, 2016). Radiogenic $\mathrm{Pb}$ increases gradually with age along the NWHR (dashed regression

776 lines). Emperor seamount triangles are averages of all data from each seamount with 2SD error

777 bars. Hawaiian Island data is the average of each volcano. Inset shows in detail ${ }^{208} \mathrm{~Pb}^{*} /{ }^{206} \mathrm{~Pb} *$

778 versus estimated volume flux $\left(\mathrm{m}^{3} / \mathrm{s}\right.$; Wessel, 2016). Age correction of ${ }^{208} \mathrm{~Pb} *{ }^{206} \mathrm{~Pb}^{*}$ is smaller

779 than datapoints.

780 Figure 4. Model of the evolution of the Hawaiian plume source at the CMB. Figure shows the

781 lowermost 800-1000 kilometers of mantle (not to scale; blue lens is an ULVZ). Black and grey

782 arrows represent generalized flow in the mantle (Steinberger, 2000; Davaille et al., 2003; Walker

783 et al., 2011; Hassan et al., 2016) and LLSVP (McNamara et al., 2010; Zhao et al., 2015; Garnero

784 et al., 2016). A: Pacific LLSVP B: The Hawaiian plume is created at the LLSVP edge where

785 temperature anomalies are greatest and large viscosity gradients stabilize an initially thermal

786 plume (Jellinek and Manga, 2004; Davies and Davies, 2009; Garnero et al., 2016). C: The plume

787 will migrate in mantle flow up the sloped northern edge of the LLSVP to a ridge where plumes

788 are dynamically stabilized over geologic time (Steinberger, 2000, 2004; Davaille et al., 2003;

789 Burke and Torsvik, 2004; Jellinek and Manga, 2004; Davies and Davies, 2009; Bower et al.,

790 2013; Hassan et al., 2015; Zhao et al., 2015). Flow into thermals perturbs ULVZ material below

791 (Li et al., 2015). D: LLSVP material is entrained in the plume and ${ }^{208} \mathrm{~Pb}^{*} /{ }^{206} \mathrm{~Pb} *$ values increase

792 in erupted lavas (Weis et al., 2011; Li et al., 2015). E: A significant amount of LLSVP (+/-

793 ULVZ) is consistently continuously entrained into the southeast side of the Hawaiian plume,

794 resulting in presence of the bilateral Loa and Kea trends observed on the Hawaiian Islands. 


\section{Figure1}

Click here to download Figure: Fig1_2column.pdf

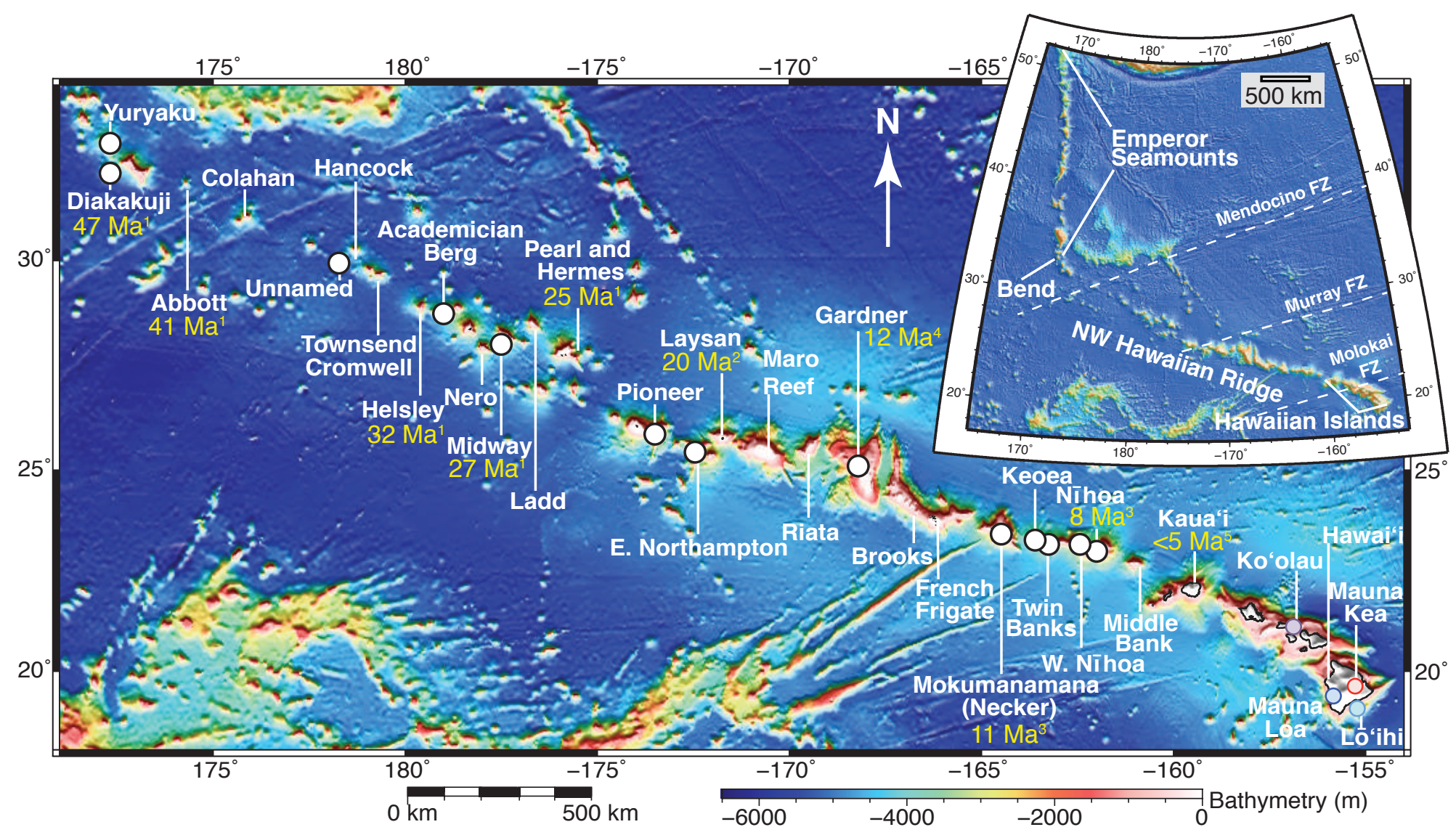




\begin{tabular}{|c|c|c|c|c|}
\hline \multirow[b]{2}{*}{$\downarrow$} & \multicolumn{2}{|c|}{ NW Hawaiian Ridge } & Emperor & Hawaiian \\
\hline & 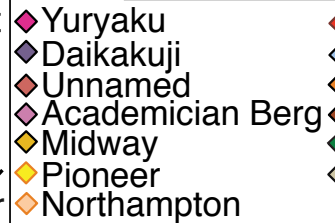 & 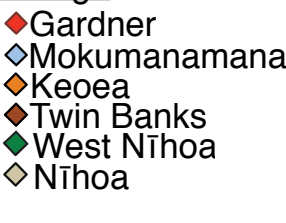 & $\begin{array}{l}\text { Seamounts } \\
\Delta \text { Meiji } \\
\Delta \text { Detroit } \\
\Delta \text { Suiko } \\
\Delta \text { Ojin } \\
\Delta \text { Koko } \\
\Delta \text { Yuryaku }\end{array}$ & $\begin{array}{l}\text { Islands } \\
\text { - Ko'olau } \\
\text { - Mauna Kea } \\
\text { o Mauna Loa } \\
\text { - Lō'ihi }\end{array}$ \\
\hline
\end{tabular}
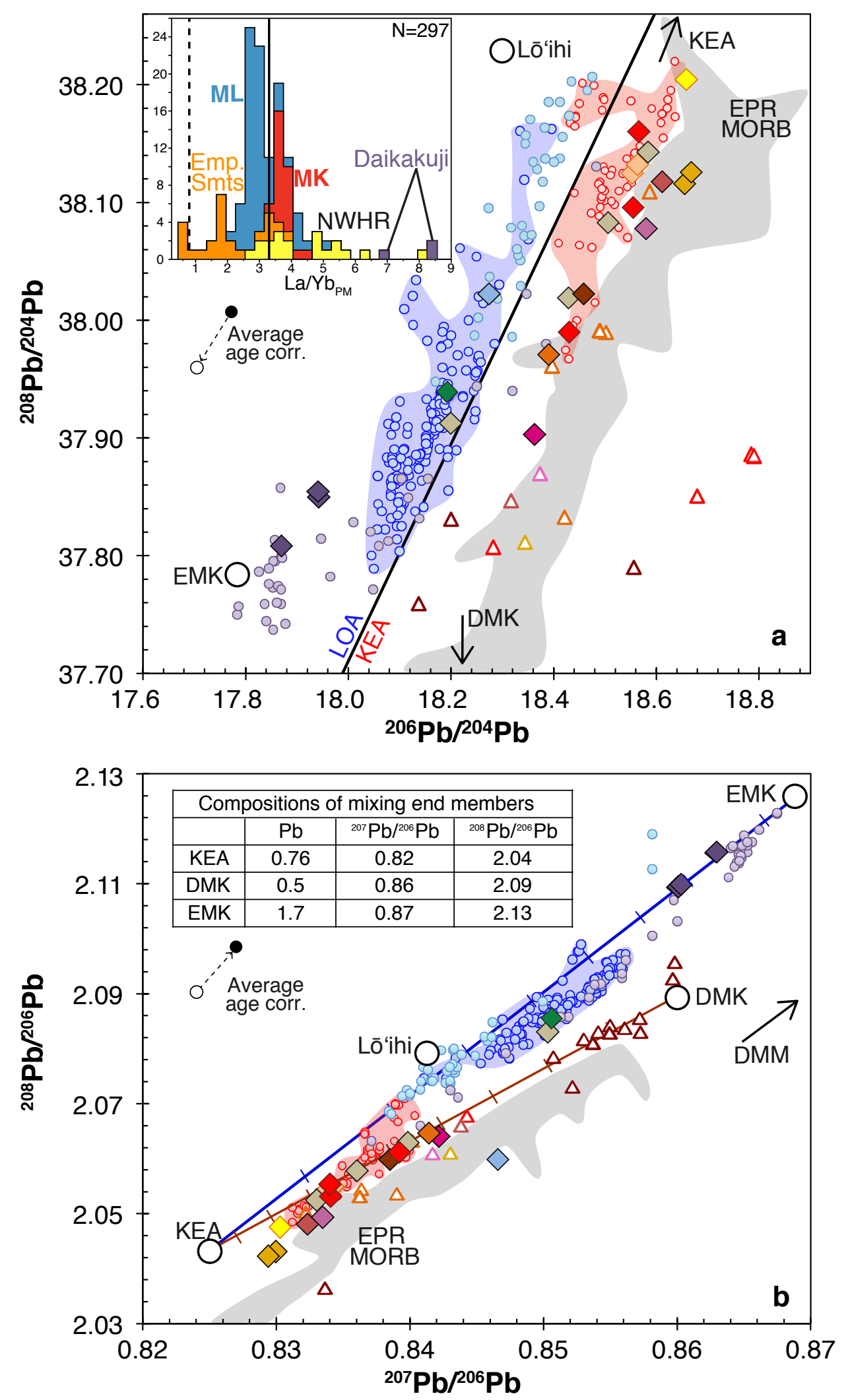


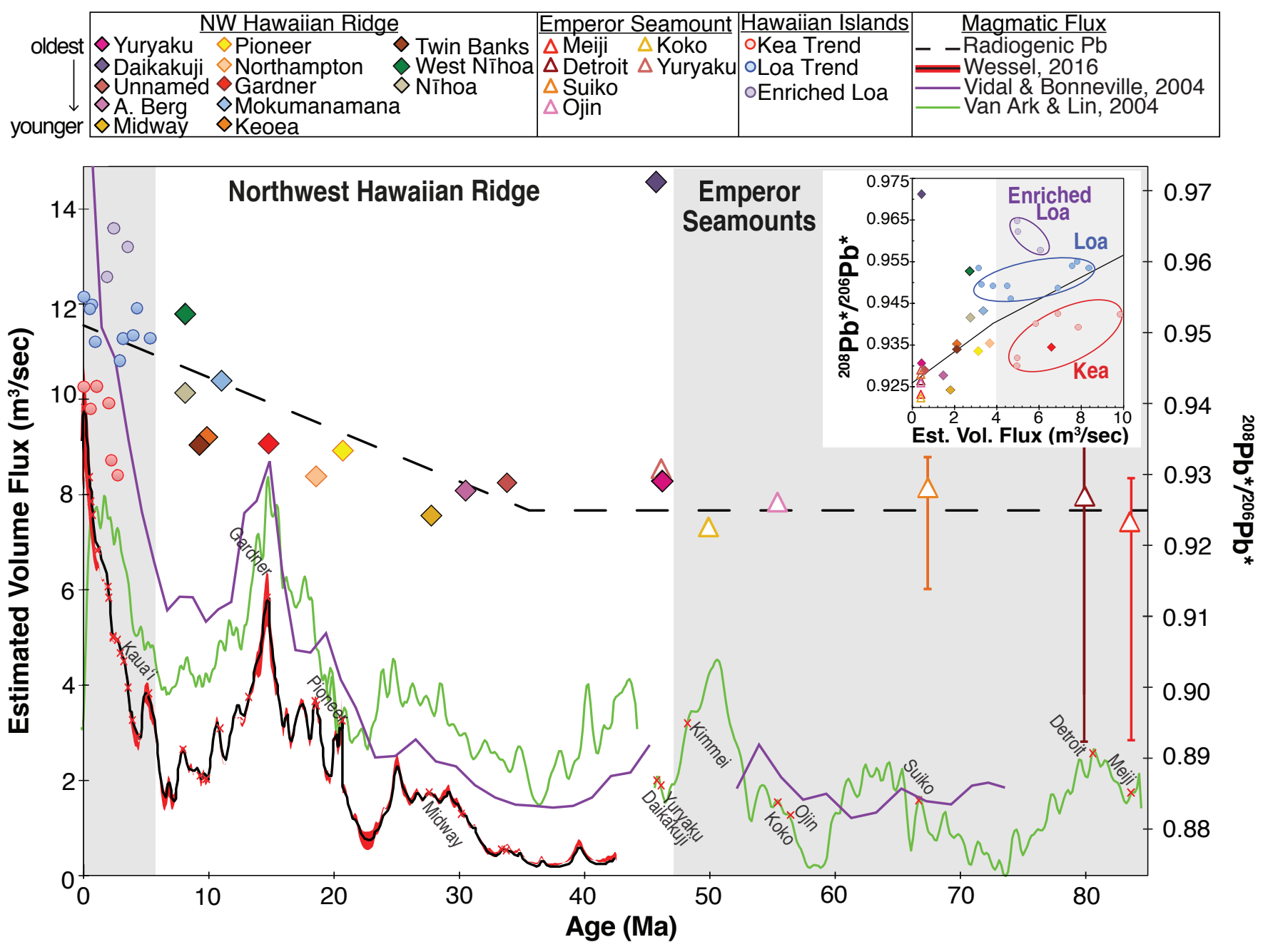


Click here to download Figure: Fig4_2column.pdf
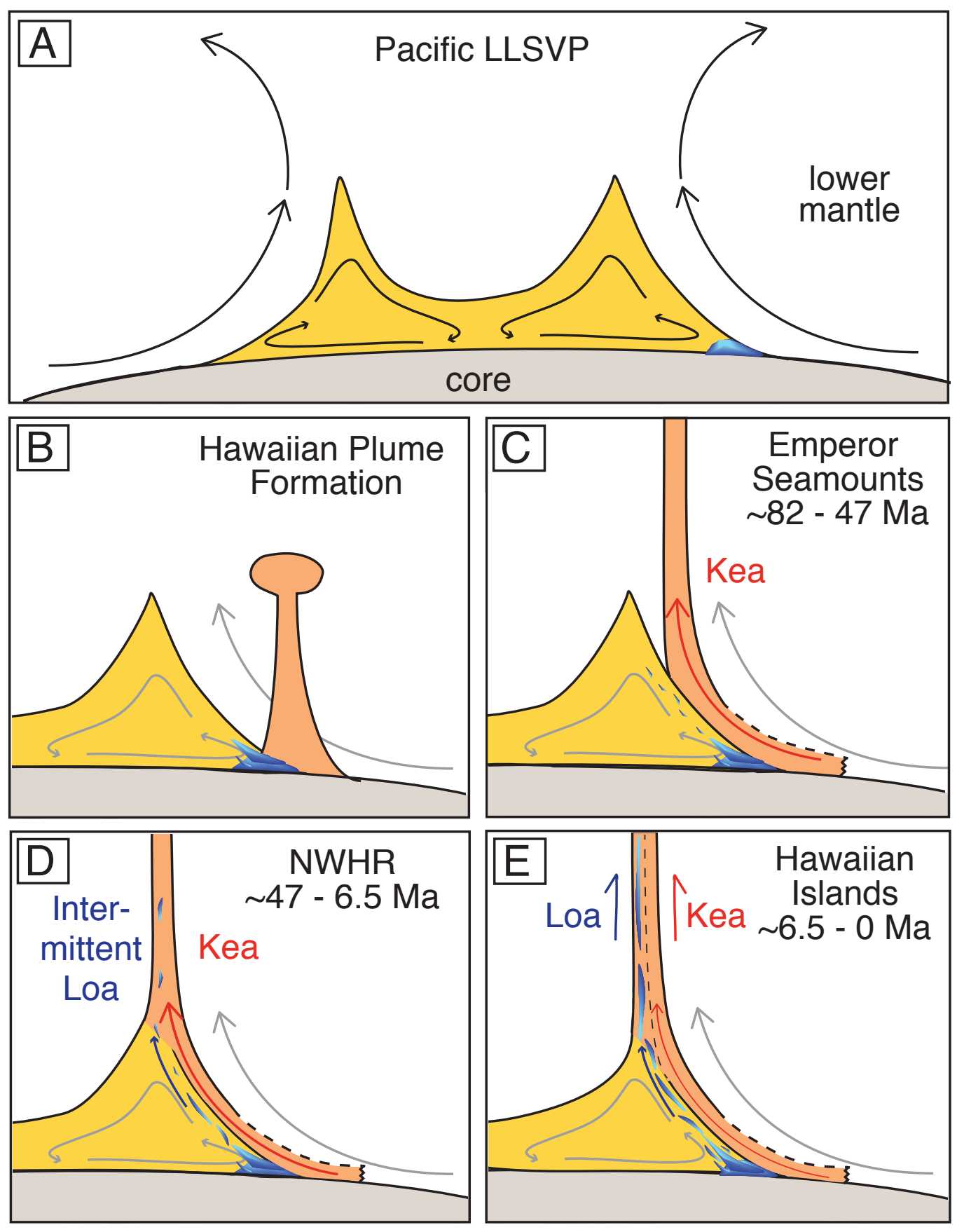
Table 1: Pb Isotopic Composition and $\mathrm{Pb}, \mathrm{U}$ and Th Concentrations of Northwest Hawaiian Ridge Basalts

\begin{tabular}{|c|c|c|c|c|c|c|c|c|c|c|c|c|c|c|c|c|c|c|c|c|}
\hline \multirow[b]{2}{*}{ Sample } & \multirow[b]{2}{*}{ Seamount } & \multirow{2}{*}{$\begin{array}{l}\text { Distance } \\
\text { from } \\
\text { Kīlauea } \\
(\mathrm{km})\end{array}$} & \multirow{2}{*}{$\begin{array}{l}\text { Est. } \\
\text { Vol. } \\
\text { Flux } \\
\left(\mathrm{m}^{3} / \mathrm{s}\right)^{8}\end{array}$} & \multirow[b]{2}{*}{$\begin{array}{l}\text { Age } \\
\text { (Ma) }\end{array}$} & \multirow[b]{2}{*}{$\begin{array}{l}\text { Age } \\
\text { Ref. }\end{array}$} & \multirow[b]{2}{*}{$\underset{\mathrm{Yb}_{\mathrm{PM}}{ }^{\mathrm{a}}}{ }$} & \multicolumn{6}{|c|}{ Measured Ratios ${ }^{\mathrm{c}}$} & \multirow[b]{2}{*}{$\begin{array}{c}\mathrm{Pb}^{\mathrm{ICP}} \\
(\mathrm{ppm})^{\mathrm{a}}\end{array}$} & \multirow[b]{2}{*}{$\begin{array}{c}\mathrm{Th}^{\mathrm{ICP}} \\
(\mathrm{ppm})^{\mathrm{a}}\end{array}$} & \multirow[b]{2}{*}{$\begin{array}{c}\mathrm{U}^{\mathrm{ICP}} \\
(\mathrm{ppm})^{\mathrm{a}}\end{array}$} & \multirow[b]{2}{*}{$\begin{array}{l}\mathrm{Th} / \\
\mathrm{U}^{\mathrm{d}}\end{array}$} & \multicolumn{4}{|c|}{$\mathrm{U}$ and Age-Corrected Isotopic Ratios } \\
\hline & & & & & & & $\begin{array}{c}{ }^{208} \mathrm{~Pb} / \\
{ }^{204} \mathrm{~Pb}\end{array}$ & $2 \sigma$ & $\begin{array}{l}{ }^{207} \mathrm{~Pb} / \\
{ }^{204} \mathrm{~Pb}\end{array}$ & $2 \sigma$ & $\begin{array}{c}{ }^{206} \mathrm{~Pb} / \\
{ }^{204} \mathrm{~Pb}\end{array}$ & $2 \sigma$ & & & & & $\begin{array}{c}{ }^{208} \mathrm{~Pb} / \\
{ }^{204} \mathrm{~Pb}\end{array}$ & $\begin{array}{l}{ }^{207} \mathrm{~Pb} / \\
{ }^{204} \mathrm{~Pb}\end{array}$ & $\begin{array}{c}{ }^{206} \mathrm{~Pb} / \\
{ }^{204} \mathrm{~Pb}\end{array}$ & $\begin{array}{c}{ }^{208} \mathrm{~Pb}^{* /} \\
{ }^{206} \mathrm{~Pb}^{*}\end{array}$ \\
\hline A-53-1 & Yuryaku & 3541 & 0.4 & 46.9 & 1 & 3.17 & 38.0527 & 21 & 15.4718 & 8 & 18.5140 & 8 & 0.74 & 0.71 & 0.314 & 2.27 & 37.904 & 15.465 & 18.363 & 0.9306 \\
\hline A-55-1 & Daikakuji & 3520 & 0.4 & 46.8 & 1 & 6.86 & 37.9374 & 22 & 15.4244 & 8 & 17.9992 & 7 & 1.53 & 1.31 & 0.436 & 3.02 & 37.809 & 15.418 & 17.869 & 0.9732 \\
\hline A-55-2 & Daikakuji & 3520 & 0.4 & 46.8 & 1 & 8.53 & 37.9977 & 26 & 15.4372 & 11 & 18.0915 & 12 & 2.22 & 2.18 & 0.672 & 3.24 & 37.850 & 15.430 & 17.942 & 0.9698 \\
\hline A-55-4 & Daikakuji & 3520 & 0.4 & 46.8 & 1 & 8.42 & 38.0094 & 23 & 15.4402 & 14 & 18.0972 & 11 & 2.16 & 2.22 & 0.689 & 3.22 & 37.855 & 15.433 & 17.941 & 0.9705 \\
\hline $84-28 \mathrm{E}$ & Unnamed & 2801 & 0.6 & 31.7 & 6 & 5.38 & 38.2106 & 27 & 15.4958 & 8 & 18.7045 & 10 & 1.70 & 1.46 & 0.474 & 3.08 & 38.119 & 15.492 & 18.612 & 0.9289 \\
\hline 84-30G & Academician Berg & 2608 & 1.3 & 31.0 & 6 & 5.41 & 38.2009 & 27 & 15.4923 & 9 & 18.7037 & 11 & 1.24 & 1.42 & 0.438 & 3.25 & 38.079 & 15.487 & 18.580 & 0.9277 \\
\hline R-1316 & Midway & 2447 & 1.8 & 27.6 & 1 & 5.09 & 38.2085 & 29 & 15.4890 & 8 & 18.7484 & 16 & 1.06 & 1.08 & 0.368 & 2.93 & 38.117 & 15.485 & 18.656 & 0.9243 \\
\hline R-1295.6 & Midway & 2447 & 1.8 & 27.6 & 1 & 4.82 & 38.2173 & 22 & 15.4890 & 8 & 18.7601 & 11 & 1.03 & 1.04 & 0.375 & 2.77 & 38.127 & 15.485 & 18.669 & 0.9241 \\
\hline P5-524-42 & Pioneer & 1998 & 3.4 & 28.0 & 7 & 4.81 & 38.2475 & 20 & 15.4949 & 5 & 18.7008 & 6 & 2.63 & 1.20 & 0.817 & 1.47 & 38.206 & 15.493 & 18.659 & 0.9335 \\
\hline 76-5-4 DD & Northampton & 1846 & 3.6 & 26.6 & 3 & 3.81 & 38.2028 & 19 & 15.4818 & 7 & 18.6307 & 8 & 0.83 & 0.83 & 0.275 & 3.01 & 38.126 & 15.478 & 18.553 & 0.9355 \\
\hline $76-5-4 A$ & Northampton & 1846 & 3.6 & 26.6 & 3 & 3.50 & 38.2039 & 23 & 15.4813 & 8 & 18.6348 & 8 & 0.84 & 0.77 & 0.277 & 2.79 & 38.133 & 15.478 & 18.564 & 0.9353 \\
\hline $76-6-7-F$ & Gardner & 1449 & 5.8 & 12.3 & 4 & 3.12 & 38.1315 & 68 & 15.4785 & 28 & 18.5903 & 30 & 0.61 & 0.53 & 0.196 & 2.69 & 38.097 & 15.477 & 18.555 & 0.9322 \\
\hline $84-40 \mathrm{E}$ & Gardner & 1449 & 5.8 & 12.3 & 4 & 3.04 & 38.0246 & 29 & 15.4690 & 12 & 18.4651 & 13 & 0.75 & 0.64 & 0.264 & 2.44 & 37.991 & 15.467 & 18.431 & 0.9332 \\
\hline 84-39B & Gardner & 1449 & 5.8 & 12.3 & 4 & 3.30 & 38.1808 & 33 & 15.4858 & 14 & 18.5857 & 13 & 1.91 & 0.93 & 0.287 & 3.24 & 38.161 & 15.485 & 18.566 & 0.9380 \\
\hline NEC-3A & Mokumanamana & 1080 & 3.1 & 10.0 & 2 & 2.79 & 37.9611 & 28 & 15.4714 & 10 & 18.3017 & 11 & 1.31 & 0.91 & 0.284 & 3.22 & 37.934 & 15.470 & 18.274 & 0.9432 \\
\hline $72-49 A$ & Keoea & 963 & 2.0 & 11.0 & 7 & 3.49 & 38.0024 & 23 & 15.4754 & 8 & 18.4213 & 9 & 0.98 & 0.85 & 1.041 & 0.81 & 37.972 & 15.474 & 18.390 & 0.9353 \\
\hline P5-688-1 & Twin Banks & 920 & 2.1 & 9.6 & 4 & 3.59 & 38.0459 & 28 & 15.4792 & 10 & 18.4813 & 9 & 0.71 & 0.55 & 0.854 & 0.64 & 38.024 & 15.478 & 18.459 & 0.9340 \\
\hline $76-9-11$ & West Nīhoa & 825 & 2.6 & 8.8 & 1 & 6.23 & 37.9402 & 25 & 15.4724 & 7 & 18.1919 & 7 & $66.2^{\mathrm{b}}$ & 1.38 & 0.694 & 1.98 & 37.940 & 15.472 & 18.191 & 0.9527 \\
\hline NIH-D4 & Nīhoa & 794 & 2.6 & 7.0 & 2 & 3.88 & 38.0444 & 19 & 15.4789 & 7 & 18.4540 & 10 & 0.78 & 0.70 & 0.211 & 3.32 & 38.020 & 15.478 & 18.429 & 0.9366 \\
\hline NIH-W11-1 & Nīhoa & 794 & 2.6 & 7.0 & 2 & 5.72 & 38.1702 & 27 & 15.4827 & 9 & 18.6103 & 9 & 0.78 & 0.74 & 0.246 & 3.02 & 38.144 & 15.481 & 18.584 & 0.9344 \\
\hline NIH-F9 & Nīhoa & 794 & 2.6 & 7.0 & 2 & 4.69 & 38.1109 & 24 & 15.4744 & 8 & 18.5338 & 9 & 0.74 & 0.73 & 0.153 & 4.76 & 38.084 & 15.473 & 18.507 & 0.9357 \\
\hline NIH-D-1-2 & Nīhoa & 794 & 2.6 & 7.0 & 2 & 8.17 & 37.9256 & 27 & 15.4752 & 9 & 18.2092 & 10 & 2.53 & 1.16 & 0.429 & 2.70 & 37.913 & 15.475 & 18.200 & 0.9488 \\
\hline
\end{tabular}

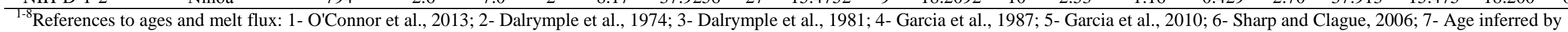

interpolating between existing ages and assuming a linear age progression of NWHR volcanoes; 8- Wessel, 2016.

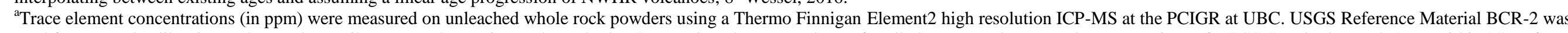

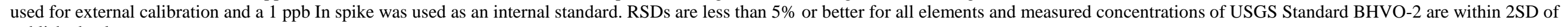
published values.

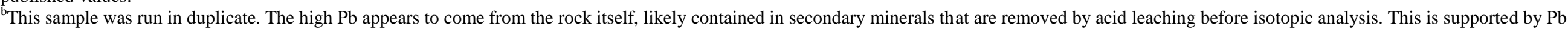
isotopic values from leached whole rock powder for this sample that plot within the field for Hawaiian shield basalts.

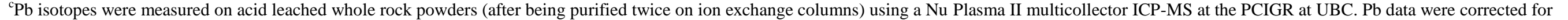

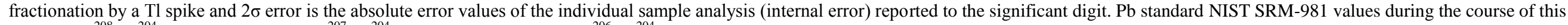
study were ${ }^{208} \mathrm{~Pb} /{ }^{204} \mathrm{~Pb}=36.7188 \pm 0.0107,{ }^{207} \mathrm{~Pb} /{ }^{204} \mathrm{~Pb}=15.4983 \pm 0.0041$, and ${ }^{206} \mathrm{~Pb} /{ }^{204} \mathrm{~Pb}=16.9418 \pm 0.0028(\mathrm{n}=102)$.

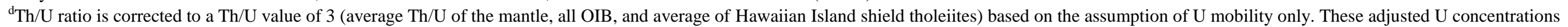
are then used to age correct measured $\mathrm{Pb}$ isotopic ratios avoiding major complications due to secondary alteration. 